OPEN ACCESS

Edited by:

Zhijun Dong,

Yantai Institute of Coastal Zone

Research (CAS), China

Reviewed by:

Susumu Ohtsuka,

Hiroshima University, Japan

Yong Jiang,

Ocean University of China, China

*Correspondence:

Xiaofeng Lin

linxf@xmu.edu.cn

${ }^{\dagger}$ These authors share first authorship

Specialty section:

This article was submitted to

Marine Evolutionary Biology, Biogeography and Species Diversity,

a section of the journal

Frontiers in Marine Science

Received: 03 January 2022

Accepted: 07 February 2022

Published: 07 March 2022

Citation:

Hu T, Wang Z, Liu W and Lin X

(2022) Taxonomy and Phylogeny

of Two Tintinnid Ciliates

of Leprotintinnus (Protista, Ciliophora,

Choreotrichida) Combining

the Loricae, Cytological, Ontogenetic

Features, and Barcoding Genes.

Front. Mar. Sci. 9:847600.

doi: 10.3389/fmars.2022.847600

\section{Taxonomy and Phylogeny of Two Tintinnid Ciliates of Leprotintinnus (Protista, Ciliophora, Choreotrichida) Combining the Loricae, Cytological, Ontogenetic Features, and Barcoding Genes}

\author{
Tao Hu${ }^{1+}$, Zhaoyi Wang ${ }^{1+}$, Weiwei $\mathrm{Liu}^{2}$ and Xiaofeng Lin ${ }^{3 *}$ \\ ${ }^{1}$ Laboratory of Protozoology, Guangzhou Key Laboratory of Subtropical Biodiversity and Biomonitoring, South China Normal \\ University, Guangzhou, China, ${ }^{2}$ Key Laboratory of Tropical Marine Bio-Resources and Ecology, South China Sea Institute \\ of Oceanology, Chinese Academy of Sciences, Guangzhou, China, ${ }^{3}$ Key Laboratory of the Ministry of Education for Coastal \\ and Wetland Ecosystem, The Fujian Provincial Key Laboratory for Coastal Ecology and Environmental Studies, College \\ of the Environment and Ecology, Xiamen University, Xiamen, China
}

Tintinnid ciliates are a highly diverse and essential group in the marine planktonic microbial loop. However, most of the known tintinnids were recorded only by the lorica characters and very few of them had been studied on their cytological features. In this study, the morphological characters of the lorica, ciliary pattern, nuclear apparatus, ontogenesis, and the molecular phylogeny of two poorly known tintinnid ciliates, Leprotintinnus nordqvisti (Brandt, 1906) Kofoid and Campbell (1929) and L. simplex Schmidt (1902), isolated from coastal waters of southern China, were investigated based on living observation, silver staining, three nuclear ribosomal DNA markers (18S, ITS1-5.8S-ITS2, and 28S genes) and one mitochondrial DNA marker (CO1 gene). For the first time, the somatic ciliary pattern of the genus Leprotintinnus was disclosed, viz., comprising a ventral, a dorsal, and a posterior kinety as well as a right, a left, and a lateral ciliary field. The diagnoses of both Leprotintinnus species were improved and the neotype was assigned. The ontogenesis of $L$. nordqvisti was in enantiotropic division mode with the new dorsal and posterior kineties generated de novo. The molecular phylogeny confirmed that Leprotintinnus species are closely related to some species of Tintinnopsis, Stylicauda, Rhizodomus, and Climacocylis. The anterior extending of the ventral kinety together with some of the lateral kinety is likely to be a distinguishing feature to determine their systematic relationships. This study also revealed that (i) the lorica of L. nordqvisti is polymorphic or plastic; (ii) Leprotintinnus tubulosus Roxas (1941) might be a synonym of L. nordqvisti; (iii) Leprotintinnus neriticus sensu Yoo et al. (1988) might be a misidentification of $L$. simplex.

Keywords: Leprotintinnus nordqvisti, Leprotintinnus simplex, Leprotintinnus tubulosus, Leprotintinnus neriticus, neotype, ontogenesis 


\section{INTRODUCTION}

Tintinnids (Ciliophora, Oligotrichea, Choreotrichida) are unique planktonic ciliates with lorica as a cell house (Adl et al., 2019). They are essential transmitters of material and energy in the marine planktonic microbial loop, by preying on phytoplankton and being preyed on by small zooplankton or fish larvae (Dolan et al., 2013; Zingel et al., 2019). Since the first record in Müller (1776), over 1,000 tintinnid species have been reported. Most of them were found in marine habitats (Kofoid and Campbell, 1929, 1939; Liu et al., 2020), and a few species occurred in brackish waters (Sniezek et al., 1991; Snyder and Brownlee, 1991; Smith et al., 2018) or fresh waters (Foissner and O'Donoghue, 1990; Petz and Foissner, 1993). The taxonomic classification of most known tintinnids solely relied on their loricae features. While the lorica is useful for species discrimination only in some cases such as ecological studies (Santoferrara et al., 2013), a huge body of literature have found that different types of loricae (polymorphism or plasticity) could be owned by the same species in the laboratory pure cultures (Gold and Morales, 1974, 1975; Laval-Peuto, 1977, 1981). Different DNA sequences were also obtained from two almost identical lorica forms (cryptic species) in field samples (Xu et al., 2012; Santoferrara et al., 2015). Hence, the lorica-based taxonomy is clearly outdated and might be unreliable compared to the cytological features (Dolan, 2016).

The ciliary pattern is one of the most important cytological features for ciliate identification, but it has been reported for less than 3\% of known tintinnids (Santoferrara and McManus, 2021). Molecular data, such as $18 \mathrm{~S}$ rDNA, ITS rDNA, etc., can supply crucial support for species discrimination of closely related ciliates. However, some variations of lorica features were not verified in the phylogenetic analysis based on gene sequences (Santoferrara et al., 2017). Therefore, it is necessary to find more comprehensive morphological features and combine them with molecular phylogeny in order to improve the specific resolution of tintinnids (Agatha and Strüder-Kypke, 2012; Santoferrara et al., 2016).

The tintinnid genus Leprotintinnus was established based on the features of lorica, namely open at both ends, surface viscous, soft, and often sparsely agglutinated (Jörgensen, 1900). Leprotintinnus pellucidus (Cleve, 1899) Jörgensen, 1901 was designated as the type species by Kofoid and Campbell (1929). This Leprotintinnus was considered a member of the family Tintinnidiidae for a long time because of its soft and often sparsely agglutinated loricae. Zhang et al. (2017) and Santoferrara et al. (2017) assigned this genus to Incertae sedis in tintinnid according to their phylogeny analysis and unclear lorica-based morphological affinity. However, this removal has not yet been confirmed by morphological features, i.e., the ciliary pattern of this genus. To date, about ten Leprotintinnus species have been recorded from coastal or fresh waters, but none of the ciliary patterns were reported.

In the present work, two Leprotintinnus species, namely Leprotintinnus nordqvisti (Brandt, 1906) Kofoid and Campbell, 1929 and Leprotintinnus simplex Schmidt (1902), collected from coastal waters of southern China, were investigated using detailed live observation, silver staining, and DNA sequencing. The cytological features of this genus were revealed for the first time. The purpose of this study was to improve our understanding of the chaotic taxonomy and phylogeny of tintinnids by combining features of the lorica, ciliary patterns, and barcoding genes.

\section{MATERIALS AND METHODS}

\section{Sample Collection, Observation, and Identification}

Both species were collected from surface water $(0-2 \mathrm{~m}$ water depth) using $20-\mu \mathrm{m}$ mesh plankton nets. Leprotintinnus nordqvisti was found in an oyster farm in Yangjiang, Guangdong Province, China in November 2019 (salinity 27\%0, pH 8.1, and water temperature $23.5^{\circ} \mathrm{C}$ ). Leprotintinnus simplex was isolated from Yuandang Lake in Xiamen, Fujian Province, China in December 2020 (salinity 28\%, pH 8.1, and water temperature $21.7^{\circ} \mathrm{C}$ ). Both species were isolated and observed in the Petri dishes of $10 \mathrm{~cm}$ diameter with a water depth of about $8 \mathrm{~mm}$, under a stereoscopic microscope (Guiguang XTL400) at room temperature. Living morphology was investigated under an optical microscope (Nikon 80i) equipped with a digital camera. The protargol silver-staining method was used to reveal the ciliary pattern and the nuclear apparatus (Ji and Wang, 2018). The protargol powder was manually synthesized following the method described by Pan et al. (2013). Counts and measurements on stained cells were performed at $1,000 \times$, while in vivo measurements were done at $400-1,000 \times$. Drawings of live specimens were based on mean measurements, while those of stained specimens were performed with the aid of a camera lucida. Terminology is mainly according to the study of Agatha and Riedel-Lorjé (2006). The classification follows the study conducted by Santoferrara and McManus (2021).

\section{Neotype Materials}

In view of the requirements of Article 75.3.6 of the International Code of Zoological Nomenclature (International Code of Zoological Nomenclature [ICZN], 1999), we designated the neotypes for $L$. nordqvisti and $L$. simplex, because (i) no type specimens are available for either species; (ii) the original descriptions lack detailed cytological and morphometric features; (iii) the neotype specimens are clearly described and illustrated, allowing for the clear identification of specific features. Unfortunately, neither of the neotypes is collected from the original type locality (coastal waters of southern China for the neotype populations vs. Brazilian coast water for L. nordqvisti and the Gulf of Siam for L. simplex). Nevertheless, it seems reasonable to designate neotypes from similar coastal habitats and necessary in order to provide stability in tintinnid taxonomy, following the argumentation of Foissner (2002), Corliss (2003).

\section{DNA Extraction, PCR Amplification, and Sequencing}

Cells for DNA extraction were isolated and rinsed five times with filtered $(0.22 \mu \mathrm{m}$ pore size $)$ habitat water. Total genomic DNA was extracted from every single cell, using the DNeasy Blood 
\& Tissue kit (Qiagen, Mississauga, ON, Canada), following the manufacturer's protocol. Cells of $L$. nordqvisti in different lorica forms, i.e., with or without an aboral flare, were separated and recorded in DNA extraction. PCR amplifications of barcoding genes (18S, ITS1-5.8S-ITS2, 28S, and CO1) were done using respective primers, including EukA (5'-AAC CTG GTT GAT CCT GCC AGT-3') (Medlin et al., 1988), 82F (5'-GAA ACT GCG AAT GGC TC-3') (Jerome et al., 1996), EukB (5’'TGA TCC TTC TGC AGG TTC ACC TAC-3') (Medlin et al., 1988), R2 (5'-AAC CTT GGA GAC CTG AT-3') (Moreira et al., 2007), and 28S rev2 (5'-ACG ATC GAT TTG CAC GTC AG-3') (Sonnenberg et al., 2007) for rDNA sequences, CiCO1 Fv2 (5'-GWT GRG CKA TGA TYA CAC C-3') and CiCO1 Rv2 (5'-ACC ATR TAC ATA TGA TGW CC-3') for CO1 sequences (Park et al., 2018). The PCR amplifications were performed using Q $5{ }^{\circledR}$ Hot Start HighFidelity DNA Polymerase (New England BioLabs, United States) to minimize the possibility of PCR amplification errors at the standard PCR protocol. The products of PCR reactions were directly sequenced in both directions using ABI 3730 sequencer by the Tianyi Huiyuan Bioscience and Technology Incorporation (Guangzhou, China).

\section{Phylogenetic Analyses}

In addition to the newly obtained sequences, other sequences used for phylogenetic analyses were downloaded from the GenBank. Oxytricha ferruginea (AF370027) and O. granulifera (AF164122) were taken as the outgroup taxa in the 18S rDNA phylogenetic tree. Urostyla grandis (AF508781), Stylonychia lemnae (AF508773), and Hemiurosomoida longa (AF508763) were used as the outgroup taxa in the ITS1-5.8s rDNA-ITS2 phylogeny analysis. Hemiurosomoida longa (AF508763) and Stylonychia mytilus (AF508774) were the outgroup taxa in our $28 \mathrm{~S}$ rDNA phylogenetic tree. Euplotes vannus (MG594918) and Diophrys appendiculata (MG594867) were the outgroup taxa in the $\mathrm{CO} 1$ gene phylogeny analysis.

The sequences were aligned with MAFFT version 7.313 (Katoh and Standley, 2013). Ambiguous positions were removed using Gblocks version 0.91b (Talavera and Castresana, 2007) with the default parameters. The final alignments comprised of 89 $18 \mathrm{~S}$ rDNA sequences with $1637 \mathrm{bp}, 61$ ITS1-5.8S-ITS2 region sequences with $481 \mathrm{bp}, 6128 \mathrm{~S}$ rDNA sequences with $656 \mathrm{bp}$, and $20 \mathrm{CO} 1$ gene sequences with $478 \mathrm{bp}$, respectively. ModelFinder was used to select the best-fit model using Akaike Information Criterion (Kalyaanamoorthy et al., 2017). Maximum likelihood (ML) analyses were inferred using IQ-TREE (Nguyen et al., 2015) under the model of GTR+R3+F (18S rDNA), SYM+R6 (ITS1-5.8S-ITS2), TN+R7+F (28S rDNA), and GTR+G4+F (CO1), respectively for 5,000 ultrafast bootstraps (Minh et al., 2013). Bayesian Inference (BI) analyses were executed with MrBayes version 3.2.6 (Ronquist et al., 2012) under the model of $\mathrm{GTR}+\mathrm{G}+\mathrm{F}(\mathrm{CO} 1)$ and $\mathrm{GTR}+\mathrm{I}+\mathrm{G}+\mathrm{F}$ (18S rDNA, ITS15.8S-ITS2 and 28S rDNA), respectively. Two parallel runs were performed. Four simultaneous Markov chain Monte Carlo simulations (MCMC) were run for 2,000,000 generations with a sampling frequency of 100 generations and a burn-in of the initial 25\% trees. Tree visualization was done in MEGA version 7.0.2 (Kumar et al., 2016) and Adobe Photoshop CC 2017.
Pairwise distances were calculated by MEGA version 7.0.2 with the $P$-distance model (Kumar et al., 2016).

\section{RESULTS}

Class Oligotrichea Bütschli, 1889

Order Choreotrichida Small and Lynn, 1985

Suborder Tintinnina Kofoid and Campbell, 1929

Genus Leprotintinnus Jörgensen, 1900

\section{Leprotintinnus nordqvisti (Brandt, 1906) Kofoid and Campbell, 1929}

\section{Improved Diagnosis of Leprotintinnus nordqvisti}

Remark. This diagnosis is improved based only on the original and the present populations, but no other known population included considering their uncertainty of species identification only based on lorica characters (e.g., Wang and Nie, 1932; Hada, 1938, 1974; Yoo et al., 1988).

Loricae cylindrical, about 80-200 $\mu \mathrm{m}$ long, anterior end slightly flared with opening 30-46 $\mu \mathrm{m}$ across, and posterior end contracted or distinctly widened with opening 28-60 $\mu \mathrm{m}$ across. Cells obconical, in vivo about 33-95 × 30-49 $\mu \mathrm{m}$. Usually two (1-3) macronuclear nodules. Ventral kinety is usually anteriorly extremely close to the collar membranes and commencing from the fifth or sixth kinety of the right ciliary field. The right ciliary field comprises 14 kineties on average, left ciliary field comprises 11 kineties on average. Lateral ciliary field comprising 17 kineties on average, the anterior parts of the rightmost kinety of the lateral ciliary field anterior extended and curving rightwards parallel to the ventral kinety. One dorsal kinety is composed of 34 dikinetids on average. One posterior kinety, with about 15 dikinetids, is positioned below the sixth or seventh kinety of the left ciliary field. One buccal membranelle. On average 21 collar membranelles, four of them elongated into the buccal cavity.

\section{Neotype of Leprotintinnus nordqvisti}

This species was originally discovered on the Brazilian coast (Brandt, 1906). No information on the holotype is available. Hence a neotype should be assigned. The neotype population was sampled from an oyster farm in Yangjiang, southern China $\left(111^{\circ} 55^{\prime} 26^{\prime \prime} \mathrm{E}, 21^{\circ} 39^{\prime} 49^{\prime \prime} \mathrm{N}\right)$. One protargol-stained slide (registration number: HT2019112261a) including the neotype (marked with a black circle) and seven slides (registration numbers: HT2019112261b-g) with voucher specimens were deposited in the Laboratory of Protozoology, Ocean University of China, Qingdao, China.

\section{Morphological Description of Leprotintinnus nordqvisti}

Loricae cylindrical, sometimes slightly curved, about 80-185 $\mu \mathrm{m}$ long (Figures 1A,D, 2A-F and Table 1). Lorica is opening at both ends. The oral margin slightly flared with an irregular opening rim 37-46 $\mu \mathrm{m}$ across, with a ratio of lorica length to anterior aperture diameter $2-4.2: 1$. The posterior end of the loricae is unstable, broken, contracted, or distinctly widened, about 28$45 \mu \mathrm{m}$ in diameter. Lorica walls are roughly transparent, soft, 


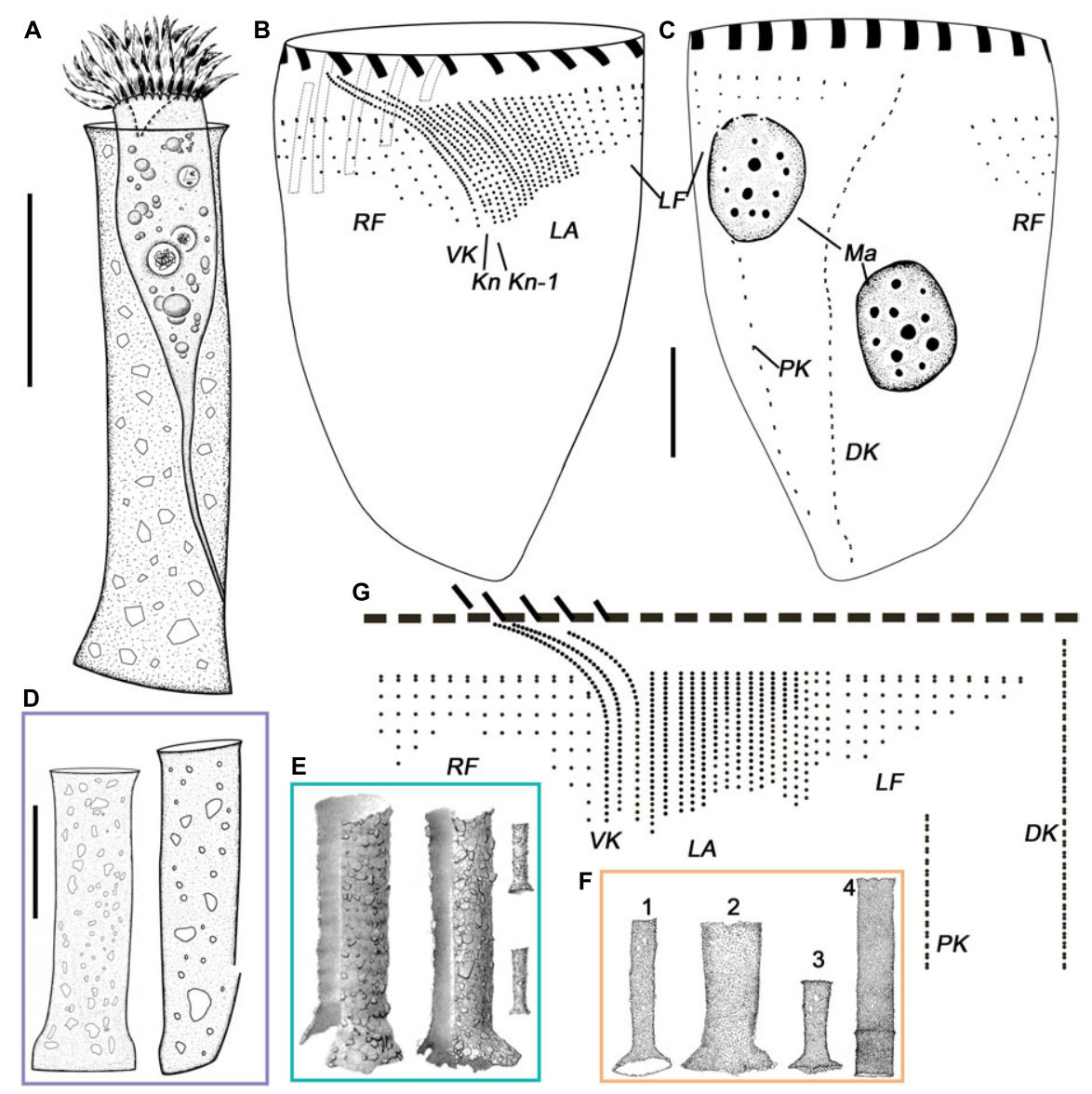

FIGURE 1 | Leprotintinnus nordqvisti from life (A,D-F) and after protargol staining (B,C,G). (A) A typical individual. (B,C) The ciliary pattern of ventral and dorsal sides of the same specimen. (D) Different shapes of loricae with agglomerated mineral particles. (E) Lateral view of loricae from Brandt (1906). (F) L. nordqvisti from Roxas (1941) (except for 4, original named L. tubulosus). (G) Kinetal map of a morphostatic specimen. DK, dorsal kinety; $K_{n}$, the last kinety of the lateral ciliary field; $\mathrm{K}_{n-1}$, the penultimate kinety of the lateral ciliary field; LA, lateral ciliary field; LF, left ciliary field; Ma, macronuclear nodules; RF, right ciliary field; VK, ventral kinety. Scale bars: $20 \mu \mathrm{m}$.

sparsely agglutinated with irregular particles, which are about 2-7 $\mu \mathrm{m}$ long (Figures 1D, 2G,H).

Fully extended cells usually $55-68 \times 28-32 \mu \mathrm{m}$ in size and elongated obconical shaped. After protargol staining, specimens about 33-95 $\times 30-49 \mu \mathrm{m}$ in size. Posterior cell proper merging gradually into a slender, wrinkled, and highly contractile peduncle (stalk). Peduncle up to $30 \mu \mathrm{m}$ long and attached to the inner wall of lorica at posterior 20 to $30 \%$ (Figures $\mathbf{1 A}, \mathbf{2 A}-\mathbf{C}, \mathbf{F}$ and Table 1). Contracted cells about $40-50 \times 30-35 \mu \mathrm{m}$ in vivo (Figure 2F). When disturbed, cells retract quickly into loricae with its contractile stalk and a posterior portion or likely escape from loricae with the naked trophont barrel-shaped, about 31$40 \times 25-35 \mu \mathrm{m}$ in size (Figure $2 \mathbf{K}$ ). Usually two (1-3) ellipsoidal or ovoidal macronuclear nodules, about 7-26 $\times 7-20 \mu \mathrm{m}$ in diameter, with nucleoli $2-4 \mu \mathrm{m}$ across after protargol staining; anterior nodule 6-17 $\mu \mathrm{m}$ posteriorly to the anterior end of the cell. One or two micronuclei attached or near to macronuclear nodules, about $2 \mu \mathrm{m}$ across (Figures $\mathbf{1 C}, \mathbf{3 H}-\mathbf{J}$ ). Neither striae, tentaculoids, accessory comb, contractile vacuole, cytopyge, nor capsule were observed. Cytoplasm colorless, sometimes with several food vacuoles up to $5 \mu \mathrm{m}$ across containing ingested yellow microalgae (Figures 2A-C,F,J,K). Swimming by rotation about the main cell axis.

The somatic ciliary pattern in the most complex type (Agatha and Strüder-Kypke, 2007), i.e., comprising a ventral, a dorsal, and a posterior kinety as well as a right, a left, and a lateral ciliary field (Figures 1B,C,G, 3A-E and Table 1). Kinetids of each ciliary row are ostensibly connected by argyrophilic fibers (Figures 3AE). Ventral kinety anterior is extremely adjacent to the collar membranelles, commencing from the fifth or sixth kinety of the right ciliary field. Ventral kinety curving leftwards and extending downward parallel to kineties of the lateral ciliary field, and terminated at anterior $40 \%$ of the cell, with $25-53$ ciliated monokinetids, anterior kinetosomes closely spaced, but more widely spaced in posterior portion, with cilia about $2 \mu \mathrm{m}$ long after impregnation (Figures 1B,G, 3A,B). The right ciliary field includes 13-15 kineties, commencing at the same level (about 5-10 $\mu \mathrm{m}$ below collar membranelles) except for the first kinety which commences about 8-14 $\mu \mathrm{m}$ below collar membranelles. The kinety in the right ciliary field is about 6-16 $\mu \mathrm{m}$ long, 


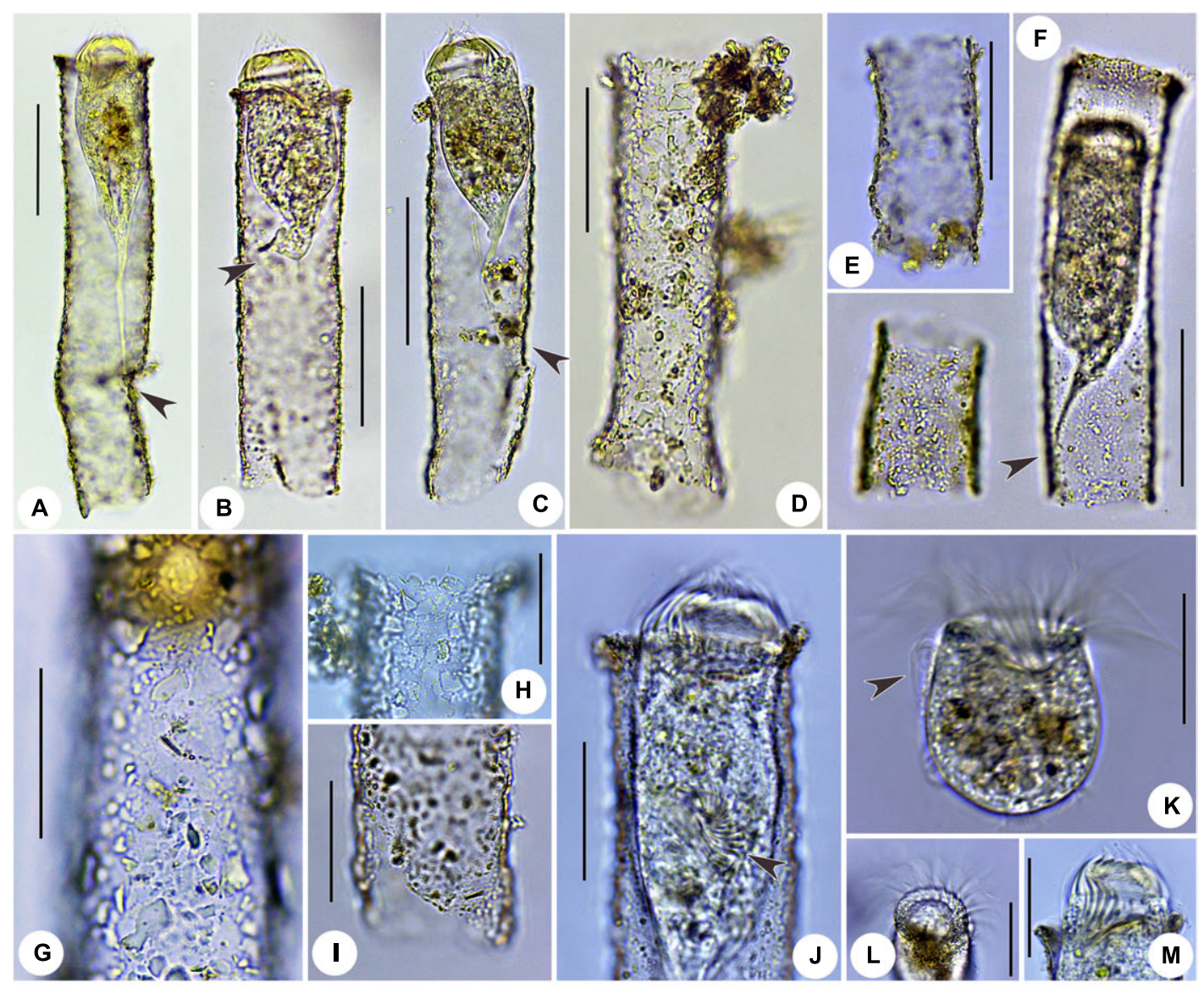

FIGURE 2 | Leprotintinnus nordqvisti in vivo. (A-F) Showing the variability of loricae shape and size, the arrows indicate the positions where the cell is properly attached to the inner wall of the lorica via the peduncle. (G) Lorica wall with numerous mineral particles. (H) Slightly flared oral marginal. (I) Broken aboral end opening. (J) Not fully contracted specimen, arrowhead denotes the oral primordium. (K) Cell proper out of the lorica, arrowhead denotes the elongated anteriormost cilia. (L) Oblique top view showing the oral membranelles. (M) Ventral view of cell showing the oral cavity. Scale bars: $50 \mu \mathrm{m}$ (A-F), $30 \mu \mathrm{m}$ (G-M).

spaced about $2 \mu \mathrm{m}$ apart, composed of 4-11 monokinetics and one anterior dikinetid (Figures 1B,C,G, 3A,E). Cilia of the right ciliary field about $2-3 \mu \mathrm{m}$ long after protargol impregnation, except for conspicuously long ones in the rightmost several kineties (about 8-12 $\mu \mathrm{m}$ long) and the anterior cilium of each dikinetids (about 15-20 $\mu \mathrm{m}$ long) (Figures 3A,E). Dorsal kinety commencing about $4-8 \mu \mathrm{m}$ posteriorly to collar membranelles, about 7-14 $\mu \mathrm{m}$ from the left ciliary fields, about $4-7 \mu \mathrm{m}$ from the right ciliary fields, and curving leftwards slightly and terminated at the posterior end of the cell. Dorsal kinety about 45-72 $\mu \mathrm{m}$ long, with 25-43 dikinetids (Figures 1B,C,G, 3C,E). Cilia is associated only with each posterior dikinetidal basal body, 5$8 \mu \mathrm{m}$ long after protargol impregnation (Figures $3 \mathbf{C , E}$ ). The left ciliary field including 10-12 kineties, commencing about 5$12 \mu \mathrm{m}$ below the collar membranelles, about 1-12 $\mu \mathrm{m}$ long, spaced about $2 \mu \mathrm{m}$ apart, composed of 1-7 monokinetids and one anterior dikinetid, but the first kinety often consisting of only one anterior dikinetid (Figures 1B,C,G, 3C-E). Cilia of the left ciliary field about 6-8 $\mu \mathrm{m}$ long after protargol impregnation, except for the anterior cilia of dikinetids measuring about $15 \mu \mathrm{m}$ (Figures 3C-E). The lateral ciliary field includes 16-19 kineties, commencing about 3-8 $\mu \mathrm{m}$ below the collar membranelles, except for (i) the last kinety $\left(\mathrm{K}_{n}\right)$ commencing anteriorly from the fourth or fifth kinety of the right ciliary field (about 1$2 \mu \mathrm{m}$ posterior to the collar membranelles) and extending parallel to the ventral kinety, and (ii) the penultimate kinety $\left(\mathrm{K}_{n-1}\right)$ commencing anterior from the second or third kinety of the right ciliary field, about 3-5 $\mu \mathrm{m}$ posterior to the collar membranelles, with anterior end lower than that of $\mathrm{K}_{n}$ but higher than that of other kineties; clockwise inclined, spaced about $1 \mu \mathrm{m}$ apart, composed of densely spaced monokinetids, kinetids and kineties more densely spaced in right portion than those in left field portion, and kinetids more widely spaced in the posterior portion of kineties than those in anterior portion; cilia about 3-4 $\mu \mathrm{m}$ long after protargol impregnation (Figures 1B,C,G, 3A,B,D). The posterior kinety commencing below the sixth or seventh kinety of the left ciliary field, about $21-45 \mu \mathrm{m}$ posteriorly to the collar membranelles, about 5-12 $\mu \mathrm{m}$ apart from the dorsal kinety, extending almost longitudinally to the posterior end of the cell, about 27-47 $\mu \mathrm{m}$ long, composed of 11-20 dikinetids with cilia about 5-8 $\mu \mathrm{m}$ long (after protargol impregnation) associated only with each posterior basal body (Figures 1B,C,G, 3C). 
Oral apparatus occupying anterior cell end (Figures $2 \mathbf{K}$ M). Adoral zone of membranelles closed, 31-48 $\mu \mathrm{m}$ across after protargol staining, perpendicular to main cell axis in contracted specimens, composed of 20 or 21 collar membranelles and invariably one buccal membranelle (Figures 1B,C,G, 2L,M, 3C,F,G and Table 1). Collar membranelles up to 8-10 $\mu \mathrm{m}$ long, separated by shallow ridges about $7-8 \mu \mathrm{m}$ wide, consisting of three rows of basal bodies, with cilia up to $30-35 \mu \mathrm{m}$ long in vivo (Figures 1B, 3C). Polykinetids of proximalmost four collar membranelles successively elongated, extending into a deep buccal cavity about 12-15 $\mu \mathrm{m}$ (Figures 1B, 3F). Single buccal membranelle, with a base about $15 \mu \mathrm{m}$ long (Figures 1B, 3F). Endoral membrane, extending across the peristomial field and right side of the buccal cavity, composed of a single row of ciliated monokinetids, probably with monostichomonad structure (Figures 1B, 3G). Argyrophilic fibers were barely recognizable.

\section{Ontogenesis of Leprotintinnus nordqvisti}

Leprotintinnus nordqvisti shows an enantiotropic division mode in which hypoapokinetal somitogenesis occurred in a subsurface pouch in the posterior half of cell proper (Figures $3 \mathbf{K}-\mathbf{T}$, $\mathbf{4 A - I}$ ). In the very early dividers, the oral primordium of the opisthe originates de novo and locates in the center of the ventral side, on the left of the posterior ventral kinety end, posteriorly to the lateral ciliary field (Figures $3 \mathbf{K}-\mathbf{N}$, 4A,B). Later, with the further proliferation of basal bodies, the anarchic field becomes larger and several membranelles differentiate (Figures 3L, 4C). One replication band emerges in each macronuclear nodules and gradually migrates through the nucleus (Figure 3L). Subsequently, the oral primordium rotates clockwise and proliferates rapidly to form a reverse C-shape, while the inner end of each membranelle plunges into the center of the body, with four membranes in the posterior end of the membranelle zone extending inward significantly longer than the other membranes (Figures 3D-F, 4D). The outer ends of the membranelles rotate counterclockwise, and the membranes extend obliquely across the peristomial rim (Figures 3M, 4D). The endoral membranelle is close to the internal edge of the upper membranes and extends across the peristomial field (Figure 3M). The two ends of the oral primordium meet to form a closed funnel-shaped membranelles zone of the opisthe, which is perpendicularly orientated to the cells' ventral side (Figures $\mathbf{3 N}$, $4 F, G)$. During the process of ontogenesis, the parental oral apparatus is inherited by the proter, and no reorganization was observed in the parental oral infraciliature.

Basal body proliferation and division of kineties occur firstly in the posterior and dorsal kineties, then in the ventral kinety, then in the right and left ciliary fields, and finally in the lateral ciliary field (Figures 3O-T, 4D-I). In the early dividers, the posterior and dorsal kineties of the opisthe start to originate de novo on the right side of the old structures (Figures 30, 4A,B). And then, the posterior end of the old ventral kinety proliferates and elongates downward along the right of the oral primordium to form the ventral kinety of opisthe (Figures $3 \mathbf{K}, \mathbf{L}, \mathbf{4 C}$ ). Subsequently, the somatic kineties of the right and left ciliary fields of the opisthe originate below each one of proter, and elongate downward by intrakinetal proliferation (Figures 3P,Q, 4D,E). In late middle dividers, the lateral ciliary field of opisthe begins to differentiate and proliferate on the posterior-right side of the oral primordium (Figure 3R). The argyrophilic structures/fibers appear to connect the corresponding kinety fragments of proter and opisthe in the right and left ciliary fields, while no connection of fibers seems to be observed in the lateral ciliary field (Figure 3R). From the middle-to-late stage, the extended ventral kinety breaks apart and differentiates into the ventral kinety of the opisthe (Figure 3S). In late middle dividers, the ciliature rows on the ventral sides of the opisthe arranged in a semi-circle around the lower margin of the developing oral primordium (Figures 3T, 4F,G). And the right and left ciliary fields of the opisthe to appear not to be connected to the older structures by argyrophilic structures/fibers anymore (Figures 3T, 4F,G).

One ante divider, i.e., a proter in cell division, was found, given its dividing macronucleus nodule and conspicuous anterior elongation of ventral kinety and penultimate two lateral kineties (Figures 3C, 4H,I). Ontogenesis and reconstruction of the interphase nuclear apparatus are not completed with the separation of proter and opisthe (at least in this division product). Two posterior kinety fragments were found arranged up and down, which may subsequently undergo connection to form the single row of the basal body (Figures 3C, 4H,I).

\section{Leprotintinnus simplex Schmidt, 1902 Improved Diagnosis of Leprotintinnus simplex}

Remark. This diagnosis is improved based only on the original and the present populations but no other known populations included considering their uncertainty of species identification only based on characters of loricae (e.g., Hada, 1938; Yoo et al., 1988).

Lorica cylindrical, about 170-425 $\mu \mathrm{m}$ long, with gradually tapering aboral end, anterior opening 41-68 $\mu \mathrm{m}$ wide, and posterior opening $30-63 \mu \mathrm{m}$ across. Two ellipsoidal macronuclear nodules. Ventral kinety is usually anterior commencing from the twelfth or thirteenth kinety of the right ciliary field and closely adjacent to collar membranelles. The right ciliary field comprises 26 kineties, left ciliary field comprises 21 kineties on average. The lateral ciliary field comprises 25 kineties on average, the rightmost kinety of the lateral ciliary field anterior curving rightwards and parallel to the ventral kinety. Dorsal kinety is composed of 79 dikinetids on average. Posterior kinety with about 28 dikinetids, located below the fifteenth kinety of the left ciliary field. One buccal membranelle; on average 18 collar membranelles, five of them elongated into the buccal cavity.

\section{Neotype of Leprotintinnus simplex}

This species was originally discovered from the Gulf of Siam, Thailand (Schmidt, 1902). No information on the holotype is available. Hence a neotype should be assigned to this species. The neotype population was sampled from the coast of Xiamen, southern China $\left(118^{\circ} 6^{\prime} 10^{\prime \prime} \mathrm{E}, 24^{\circ} 28^{\prime} 54^{\prime \prime} \mathrm{N}\right)$. One protargol-stained slide (registration number: HT20201228107a) including the neotype (marked with a black circle) and four slides (registration numbers: HT20201228107b-e) with voucher 
TABLE 1 | Morphometric data of Leprotintinnus nordqvisti (upper line) and L. simplex (lower line).

\begin{tabular}{|c|c|c|c|c|c|c|c|c|}
\hline Characteristics & Min & Max & $\bar{x}$ & $\mathbf{M}$ & SD & SE & CV & $\mathbf{N}$ \\
\hline \multirow[t]{2}{*}{ Lorica, total length } & 80.0 & 185.0 & 137.1 & 137.5 & 22.2 & 5.1 & 16.2 & 19 \\
\hline & 170.0 & 425.0 & 253.8 & 227.5 & 67.9 & 15.2 & 26.7 & 20 \\
\hline \multirow[t]{2}{*}{ Anterior aperture diameter } & 37.0 & 46.0 & 41.2 & 40.0 & 2.9 & 0.7 & 6.9 & 19 \\
\hline & 57.0 & 68.0 & 63.4 & 63.0 & 3.6 & 0.8 & 5.7 & 20 \\
\hline \multirow[t]{2}{*}{ Posterior opening diameter } & 28.0 & 45.0 & 34.8 & 35.0 & 4.5 & 1.0 & 12.8 & 19 \\
\hline & 30.0 & 63.0 & 53.2 & 55.0 & 6.3 & 1.4 & 11.8 & 20 \\
\hline \multirow[t]{2}{*}{ Lorica total length: anterior aperture, ratio } & 2.0 & 4.2 & 3.3 & 3.2 & 0.6 & 0.1 & 17.3 & 19 \\
\hline & 3.0 & 6.5 & 4.0 & 3.7 & 0.9 & 0.2 & 22.9 & 20 \\
\hline \multirow[t]{2}{*}{ Cell proper, length } & 33.0 & 95.0 & 61.0 & 60.0 & 14.6 & 2.9 & 23.9 & 25 \\
\hline & 45.0 & 130.0 & 70.7 & 64.0 & 22.3 & 5.8 & 31.5 & 15 \\
\hline \multirow[t]{2}{*}{ Cell proper, width } & 30.0 & 49.0 & 39.8 & 40.0 & 5.3 & 1.1 & 13.3 & 25 \\
\hline & 47.0 & 65.0 & 53.6 & 53.0 & 4.8 & 1.2 & 9.0 & 15 \\
\hline \multirow[t]{2}{*}{ Cell proper length:width, ratio } & 0.9 & 2.3 & 1.5 & 1.6 & 0.3 & 0.1 & 21.3 & 25 \\
\hline & 0.8 & 2.0 & 1.3 & 1.3 & 0.3 & 0.1 & 25.7 & 15 \\
\hline \multirow[t]{2}{*}{ Macronucleus nodules, number } & 1.0 & 3.0 & 2.0 & 2.0 & 0.4 & 0.1 & 20.7 & 30 \\
\hline & 2.0 & 3.0 & 2.1 & 2.0 & 0.2 & 0.1 & 12.1 & 15 \\
\hline \multirow[t]{2}{*}{ Anterior macronucleus nodule, length } & 7.0 & 20.0 & 14.6 & 15.0 & 3.1 & 0.6 & 21.1 & 25 \\
\hline & 12.0 & 35.0 & 20.3 & 20.0 & 5.6 & 1.4 & 27.5 & 15 \\
\hline \multirow[t]{2}{*}{ Anterior macronucleus nodule, width } & 7.0 & 20.0 & 12.9 & 12.0 & 3.7 & 0.7 & 28.7 & 25 \\
\hline & 10.0 & 22.0 & 14.1 & 13.0 & 3.8 & 1.0 & 27.3 & 15 \\
\hline \multirow[t]{2}{*}{ Posterior macronucleus nodule, length } & 10.0 & 26.0 & 16.6 & 16.0 & 3.2 & 0.6 & 19.3 & 25 \\
\hline & 10.0 & 33.0 & 21.7 & 20.0 & 6.5 & 1.7 & 29.9 & 15 \\
\hline \multirow[t]{2}{*}{ Posterior macronucleus nodule, width } & 7.0 & 17.0 & 11.6 & 11.0 & 2.5 & 0.5 & 21.8 & 25 \\
\hline & 9.0 & 20.0 & 15.0 & 15.0 & 3.0 & 0.8 & 19.9 & 15 \\
\hline \multirow[t]{2}{*}{ Anterior cell end to anterior macronucleus nodule, distance } & 6.0 & 17.0 & 10.5 & 11.0 & 2.3 & 0.5 & 21.6 & 25 \\
\hline & 8.0 & 25.0 & 17.3 & 16.0 & 4.2 & 1.1 & 24.4 & 15 \\
\hline \multirow[t]{2}{*}{ Micronuclei, number } & 1.0 & 2.0 & 1.1 & 1.0 & 0.3 & 0.1 & 29.4 & 8 \\
\hline & - & - & - & - & - & - & - & - \\
\hline \multirow[t]{2}{*}{ Micronucleus, diameter } & 2.0 & 2.0 & 2.0 & 2.0 & 0.0 & 0.0 & 0.0 & 8 \\
\hline & - & - & - & - & - & - & - & - \\
\hline \multirow[t]{2}{*}{ Ventral kinety, length } & 25.0 & 42.0 & 32.0 & 32.0 & 4.8 & 1.3 & 15.1 & 15 \\
\hline & 32.0 & 65.0 & 47.7 & 51.0 & 12.0 & 3.1 & 25.2 & 15 \\
\hline \multirow[t]{2}{*}{ Ventral kinety, number of kinetids } & 25.0 & 53.0 & 41.6 & 42.0 & 7.3 & 1.9 & 17.5 & 15 \\
\hline & 48.0 & 84.0 & 67.2 & 64.0 & 11.4 & 2.9 & 17.0 & 15 \\
\hline \multirow[t]{2}{*}{ Ventral kinety, distance to anterior end of cell } & 1.0 & 1.0 & 1.0 & 1.0 & 0.0 & 0.0 & 0.0 & 15 \\
\hline & 1.0 & 1.0 & 1.0 & 1.0 & 0.0 & 0.0 & 0.0 & 15 \\
\hline Dorsal kinety, length & 45.0 & 72.0 & 57.6 & 57.0 & 8.7 & 2.2 & 15.1 & 15 \\
\hline & 56.0 & 141.0 & 83.5 & 73.0 & 23.6 & 6.1 & 28.3 & 15 \\
\hline Dorsal kinety, number of dikinetids & 25.0 & 43.0 & 33.6 & 36.0 & 6.1 & 1.4 & 18.2 & 20 \\
\hline & 61.0 & 103.0 & 79.1 & 78.0 & 11.7 & 3.0 & 14.8 & 15 \\
\hline Dorsal kinety, distance to right ciliary field & 4.0 & 8.0 & 5.9 & 6.0 & 1.1 & 0.3 & 18.3 & 11 \\
\hline & 3.0 & 12.0 & 6.5 & 6.0 & 2.9 & 0.9 & 45.2 & 10 \\
\hline Dorsal kinety, distance to left ciliary field & 7.0 & 14.0 & 10.3 & 11.0 & 2.2 & 0.7 & 21.2 & 11 \\
\hline & 7.0 & 20.0 & 15.4 & 17.5 & 4.6 & 1.5 & 29.9 & 10 \\
\hline Dorsal kinety, distance to collar membranelles & 4.0 & 7.0 & 5.2 & 5.0 & 0.9 & 0.2 & 17.8 & 20 \\
\hline & 2.0 & 5.0 & 3.5 & 3.0 & 1.0 & 0.3 & 29.5 & 15 \\
\hline Posterior kinety, length & 27.0 & 47.0 & 36.2 & 35.0 & 6.3 & 1.9 & 17.5 & 11 \\
\hline & 20.0 & 82.0 & 41.3 & 35.0 & 15.7 & 4.0 & 37.9 & 15 \\
\hline Posterior kinety, number of dikinetids & 11.0 & 20.0 & 14.5 & 14.0 & 2.3 & 0.6 & 15.9 & 15 \\
\hline & 19.0 & 40.0 & 27.7 & 27.0 & 6.0 & 1.5 & 21.6 & 15 \\
\hline Posterior kinety, distance to dorsal kinety & 5.0 & 12.0 & 6.6 & 6.0 & 2.0 & 0.5 & 30.2 & 15 \\
\hline & 3.0 & 24.0 & 11.5 & 12.0 & 4.6 & 1.2 & 39.9 & 15 \\
\hline Posterior kinety, distance to collar membranelles & 21.0 & 45.0 & 28.9 & 28.0 & 5.8 & 1.5 & 20.1 & 15 \\
\hline
\end{tabular}


TABLE 1 | (Continued)

\begin{tabular}{|c|c|c|c|c|c|c|c|c|}
\hline Characteristics & Min & Max & $\bar{x}$ & $\mathbf{M}$ & SD & SE & cV & $\mathbf{N}$ \\
\hline & 18.0 & 50.0 & 34.3 & 35.0 & 8.7 & 2.3 & 25.5 & 15 \\
\hline \multirow[t]{2}{*}{ Right ciliary field, number of kineties } & 13.0 & 15.0 & 13.5 & 13.0 & 0.6 & 0.1 & 4.2 & 25 \\
\hline & 24.0 & 27.0 & 25.6 & 26.0 & 0.8 & 0.2 & 3.3 & 17 \\
\hline \multirow[t]{2}{*}{ Kinety 1 in right ciliary field, length } & 6.0 & 16.0 & 10.7 & 10.0 & 2.9 & 0.8 & 27.3 & 15 \\
\hline & 10.0 & 21.0 & 14.9 & 15.0 & 3.5 & 0.9 & 23.4 & 15 \\
\hline \multirow[t]{2}{*}{ Kinety 1 in right ciliary field, number of kinetids } & 4.0 & 11.0 & 6.6 & 6.0 & 2.0 & 0.5 & 29.7 & 15 \\
\hline & 7.0 & 13.0 & 10.5 & 10.0 & 1.8 & 0.5 & 16.9 & 15 \\
\hline \multirow[t]{2}{*}{ Kinety 1 in right ciliary field, distance to collar membranelles } & 8.0 & 14.0 & 10.7 & 10.0 & 1.8 & 0.5 & 16.8 & 15 \\
\hline & 10.0 & 25.0 & 14.6 & 14.0 & 4.5 & 1.2 & 30.6 & 15 \\
\hline \multirow[t]{2}{*}{ Kinety $\mathrm{n}$ in right ciliary field, length } & 7.0 & 11.0 & 9.2 & 10.0 & 1.5 & 0.5 & 16.6 & 11 \\
\hline & 8.0 & 22.0 & 12.9 & 13.0 & 3.7 & 1.0 & 28.9 & 15 \\
\hline \multirow[t]{2}{*}{ Kinety $\mathrm{n}$ in right ciliary field, number of kinetids } & 4.0 & 6.0 & 4.4 & 4.0 & 0.6 & 0.2 & 14.7 & 11 \\
\hline & 5.0 & 12.0 & 8.2 & 9.0 & 2.1 & 0.6 & 26.0 & 15 \\
\hline \multirow[t]{2}{*}{ Kinety $\mathrm{n}$ in right ciliary field, distance to collar membranelles } & 5.0 & 10.0 & 7.6 & 8.0 & 1.4 & 0.4 & 18.7 & 11 \\
\hline & 7.0 & 15.0 & 10.2 & 9.0 & 3.1 & 0.8 & 30.8 & 15 \\
\hline \multirow[t]{2}{*}{ Lateral ciliary field, number of kineties } & 16.0 & 19.0 & 17.4 & 17.0 & 0.7 & 0.1 & 4.3 & 25 \\
\hline & 23.0 & 27.0 & 24.8 & 24.0 & 1.6 & 0.4 & 6.6 & 15 \\
\hline \multirow[t]{2}{*}{ Lateral ciliary field, width } & 25.0 & 35.0 & 29.5 & 30.0 & 3.3 & 1.3 & 11.2 & 6 \\
\hline & 30.0 & 42.0 & 36.3 & 37.0 & 4.1 & 1.1 & 11.2 & 15 \\
\hline \multirow[t]{2}{*}{ Kinety 1 in lateral ciliary field, length } & 5.0 & 11.0 & 8.1 & 8.0 & 1.9 & 0.6 & 23.1 & 10 \\
\hline & 11.0 & 20.0 & 15.3 & 15.0 & 2.2 & 0.6 & 14.2 & 15 \\
\hline \multirow[t]{2}{*}{ Kinety 1 in lateral ciliary field, number of kinetids } & 4.0 & 10.0 & 6.5 & 6.5 & 1.7 & 0.6 & 26.9 & 10 \\
\hline & 9.0 & 14.0 & 11.6 & 12.0 & 1.4 & 0.4 & 12.1 & 15 \\
\hline \multirow[t]{2}{*}{ Kinety 1 in lateral ciliary field, distance to collar membranelles } & 3.0 & 8.0 & 5.7 & 5.5 & 1.3 & 0.4 & 23.6 & 10 \\
\hline & 4.0 & 9.0 & 5.9 & 5.0 & 1.4 & 0.4 & 23.4 & 15 \\
\hline \multirow[t]{2}{*}{ Kinety $n-1$ in lateral ciliary field, length } & 16.0 & 25.0 & 20.6 & 21.0 & 3.3 & 1.5 & 15.8 & 5 \\
\hline & 30.0 & 54.0 & 39.4 & 38.0 & 8.2 & 3.7 & 20.8 & 5 \\
\hline \multirow[t]{2}{*}{ Kinety $n-1$ in lateral ciliary field, number of kinetids } & 20.0 & 38.0 & 29.2 & 28.0 & 6.6 & 2.9 & 22.4 & 5 \\
\hline & 42.0 & 58.0 & 49.4 & 48.0 & 5.4 & 2.4 & 10.8 & 5 \\
\hline \multirow[t]{2}{*}{ Kinety $n$ - 1 in lateral ciliary field, distance to collar membranelles } & 3.0 & 5.0 & 4.2 & 4.5 & 0.9 & 0.3 & 20.8 & 10 \\
\hline & 2.0 & 7.0 & 4.6 & 5.0 & 1.9 & 0.8 & 40.3 & 5 \\
\hline \multirow[t]{2}{*}{ Kinety $n$ in lateral ciliary field, length } & 18.0 & 26.0 & 23.0 & 23.0 & 2.8 & 1.2 & 12.0 & 5 \\
\hline & 28.0 & 59.0 & 46.8 & 48.0 & 10.6 & 4.7 & 22.6 & 5 \\
\hline \multirow[t]{2}{*}{ Kinety $\mathrm{n}$ in lateral ciliary field, number of kinetids } & 24.0 & 46.0 & 32.0 & 30.0 & 7.5 & 3.3 & 23.4 & 5 \\
\hline & 48.0 & 78.0 & 61.0 & 60.0 & 9.9 & 4.4 & 16.2 & 5 \\
\hline \multirow[t]{2}{*}{ Kinety $n$ in lateral ciliary field, distance to collar membranelles } & 1.0 & 2.0 & 1.2 & 1.0 & 0.4 & 0.2 & 33.3 & 5 \\
\hline & 1.0 & 2.0 & 1.4 & 1.0 & 0.5 & 0.2 & 35.0 & 5 \\
\hline Left ciliary field, number of kineties & 10.0 & 12.0 & 11.2 & 11.0 & 0.6 & 0.1 & 5.1 & 25 \\
\hline & 18.0 & 22.0 & 20.5 & 21.0 & 1.3 & 0.6 & 6.4 & 15 \\
\hline Kinety 1 in left ciliary field, length & 1.0 & 5.0 & 3.0 & 3.0 & 1.5 & 0.5 & 51.6 & 10 \\
\hline & 2.0 & 5.0 & 3.0 & 3.0 & 0.8 & 0.4 & 27.2 & 15 \\
\hline Kinety 1 in left ciliary field, number of kinetids & 1.0 & 3.0 & 1.6 & 1.5 & 0.7 & 0.2 & 41.5 & 10 \\
\hline & 1.0 & 3.0 & 2.0 & 2.0 & 0.7 & 0.3 & 36.5 & 15 \\
\hline Kinety 1 in left ciliary field, distance to collar membranelles & 5.0 & 7.0 & 6.3 & 6.0 & 0.6 & 0.2 & 10.2 & 10 \\
\hline & 4.0 & 8.0 & 6.3 & 6.0 & 1.3 & 0.6 & 20.6 & 15 \\
\hline Kinety $n$ in left ciliary field, length & 7.0 & 12.0 & 9.0 & 8.5 & 2.0 & 0.6 & 22.2 & 10 \\
\hline & 10.0 & 19.0 & 15.0 & 16.0 & 2.4 & 1.1 & 16.0 & 15 \\
\hline Kinety $n$ in left ciliary field, number of kinetids & 4.0 & 7.0 & 5.4 & 5.5 & 0.9 & 0.3 & 17.0 & 10 \\
\hline & 5.0 & 12.0 & 9.6 & 10.0 & 1.6 & 0.7 & 16.9 & 15 \\
\hline Kinety $n$ in left ciliary field, distance to collar membranelles & 7.0 & 12.0 & 9.0 & 8.5 & 2.0 & 0.6 & 22.2 & 10 \\
\hline & 3.0 & 8.0 & 5.5 & 5.0 & 1.3 & 0.6 & 22.7 & 15 \\
\hline Adoral zone of membranelles, diameter & 31.0 & 48.0 & 40.9 & 41.0 & 4.4 & 0.9 & 10.9 & 25 \\
\hline & 52.0 & 67.0 & 56.7 & 54.0 & 4.6 & 2.1 & 8.2 & 15 \\
\hline
\end{tabular}


TABLE 1 | (Continued)

\begin{tabular}{|c|c|c|c|c|c|c|c|c|}
\hline Characteristics & Min & Max & $\bar{x}$ & $\mathbf{M}$ & SD & SE & CV & $\mathbf{N}$ \\
\hline \multirow[t]{2}{*}{ Collar membranelles, number } & 20.0 & 21.0 & 20.5 & 21.0 & 0.5 & 0.1 & 2.4 & 25 \\
\hline & 17.0 & 18.0 & 17.8 & 18.0 & 0.4 & 0.2 & 2.2 & 15 \\
\hline \multirow[t]{2}{*}{ Collar membranelles, number of elongated ones } & 4.0 & 4.0 & 4.0 & 4.0 & 0.0 & 0.0 & 0.0 & 25 \\
\hline & 5.0 & 5.0 & 5.0 & 5.0 & 0.0 & 0.0 & 0.0 & 15 \\
\hline \multirow[t]{2}{*}{ Buccal membranelle, number } & 1.0 & 1.0 & 1.0 & 1.0 & 0.0 & 0.0 & 0.0 & 25 \\
\hline & 1.0 & 1.0 & 1.0 & 1.0 & 0.0 & 0.0 & 0.0 & 25 \\
\hline
\end{tabular}

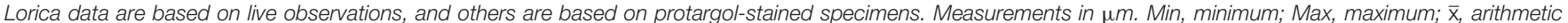
mean; M, median; SD, standard deviation; SE, standard error of arithmetic mean; CV, coefficient of variation in \%; N, number of specimens examined; -, Null value.

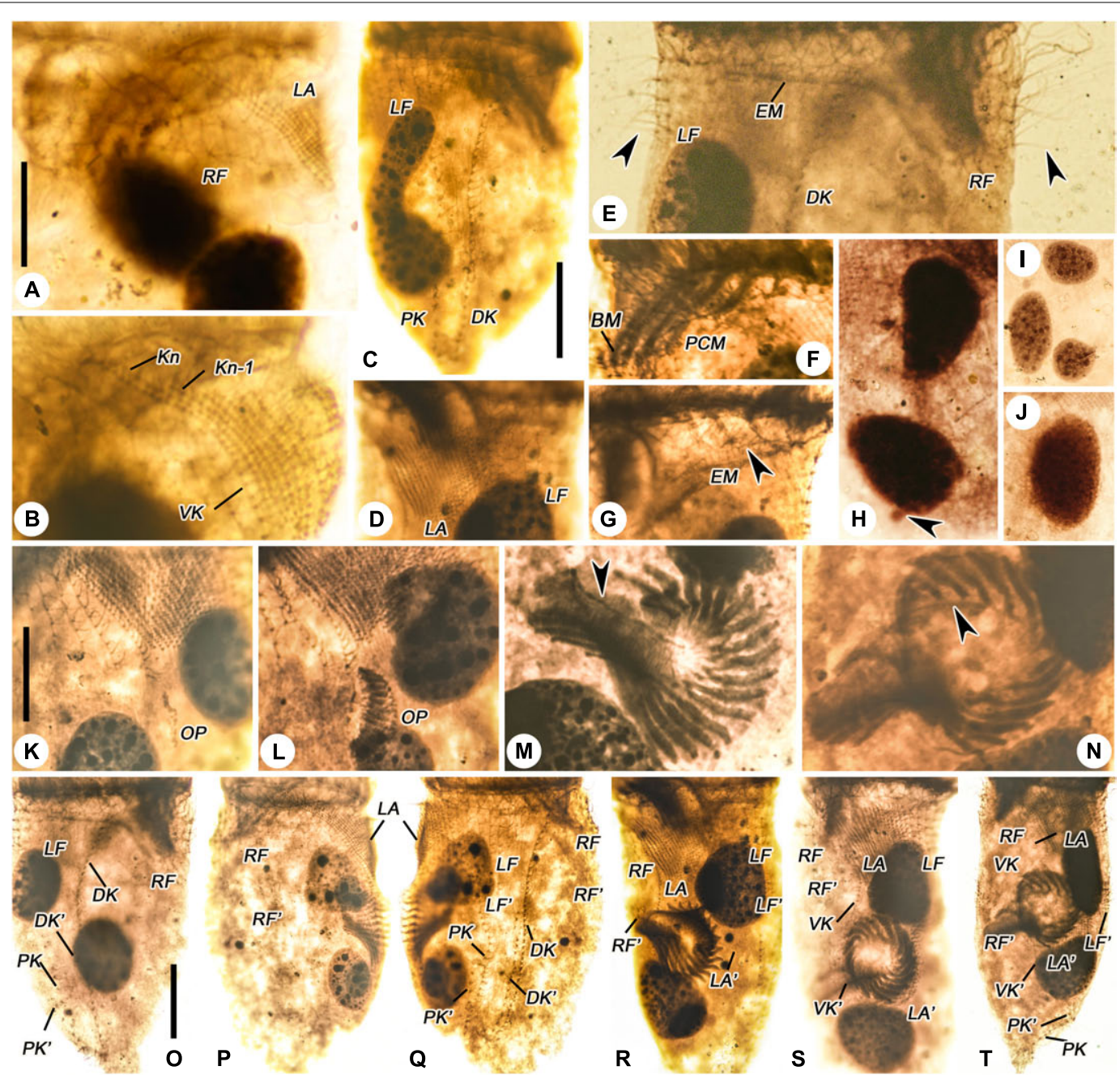

FIGURE 3 | Leprotintinnus nordqvisti after protargol staining. (A,B) Ventrolateral view showing the ventral kinety, right ciliary field, and lateral ciliary field. (C) Dorsal view of an anterdivider, showing left ciliary field, dorsal and posterior kineties. (D) Lateral ciliary field and left ciliary field. (E) The anterior portion of dorsal kinety, left ciliary field, and right ciliary field, arrows indicate the elongated anterior cilia of the right and left ciliary fields. (F) Prolonged collar membranelles and buccal membranelle. (G) Arrowhead shows the endoral membrane. (H-J) Macronuclear nodules and micronuclei (arrowhead). (K,L) Ventral view of early dividers. (M,N) Oral primordium, arrows indicate opisthe's endoral membranelle. (O) Dorsal view of the same very early divide. (P,Q) Ventral and dorsal views of the same early middle divide. (R) Ventral view of the middle divider. (S) Ventral view of the late middle divide, showing the split of the ventral kinety. (T) Ventral view of the middle-to-late divider. BM, buccal membranelle; DK, DK', proter's and opisthe's dorsal kineties; EM, endoral membranelle; LA, LA', proter's and opisthe's lateral ciliary fields; LF, LF', proter's and opisthe's left ciliary fields; OP, oral primordium; PCM, prolonged collar membranelles; RF, RF', proter's and opisthe's right ciliary fields; VK, VK', proter's and opisthe's ventral kineties. Scale bars: $20 \mu \mathrm{m}$. 

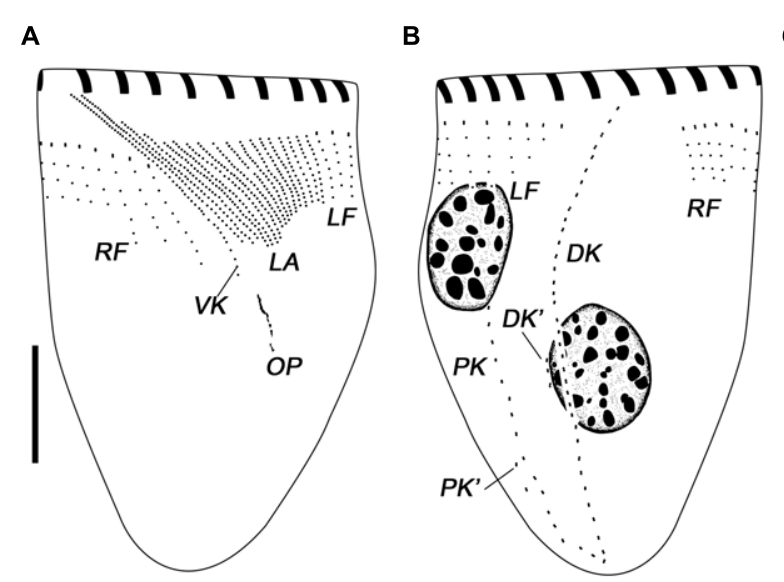

\section{C}

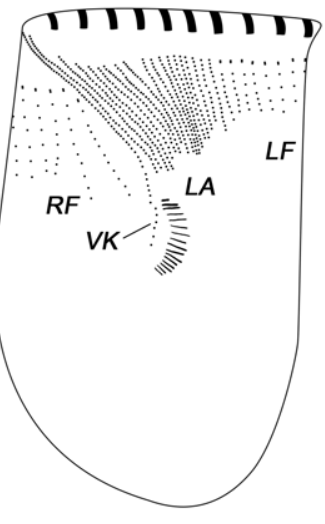

D

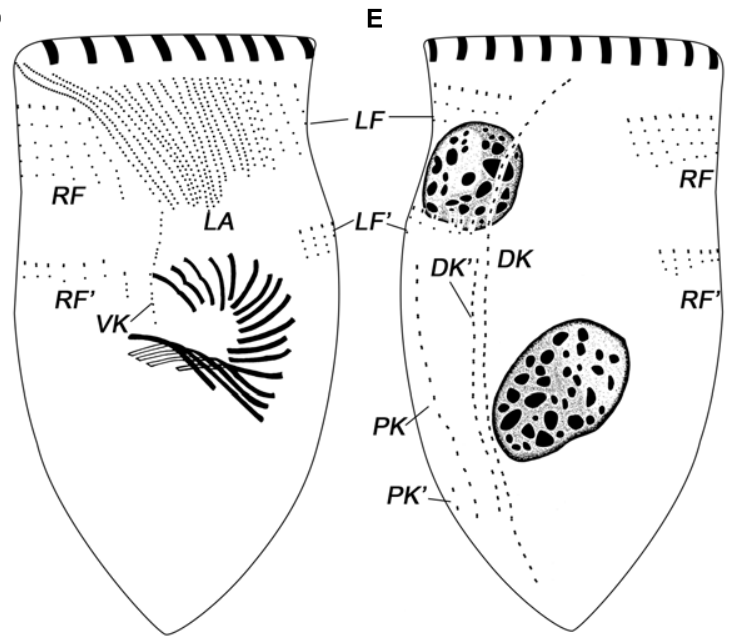

$\mathbf{F}$

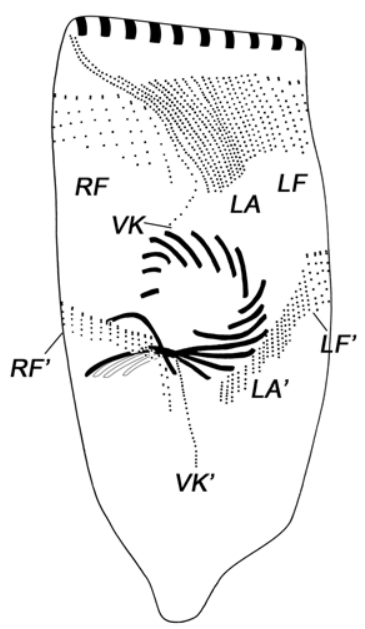

G

H
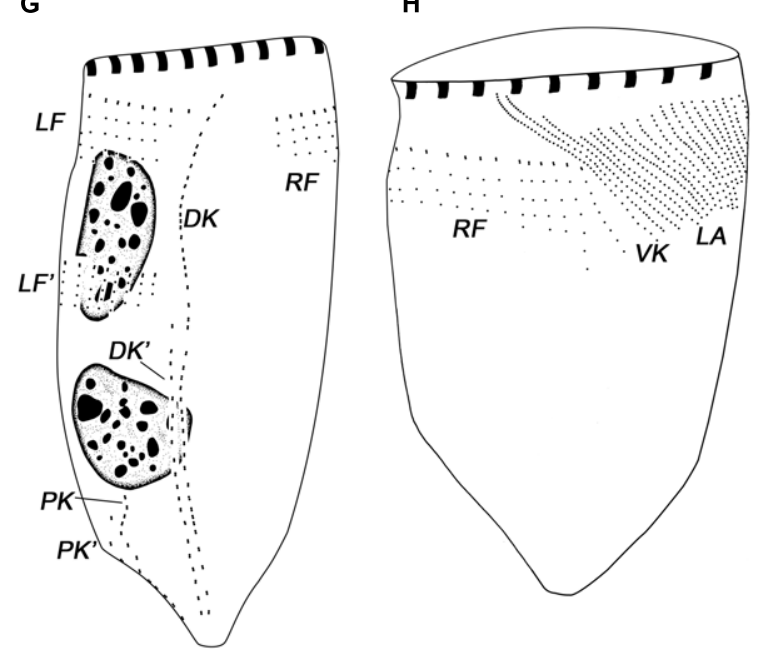

I

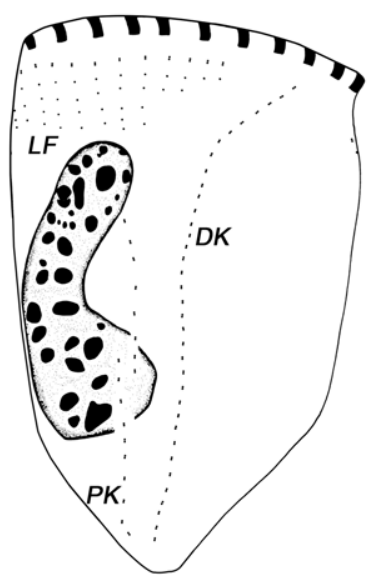

FIGURE 4 | Leprotintinnus nordqvisti, dividers after protargol staining. (A,B) Ventral and dorsal views of the same very early divider. (C) Ventral views of an early divider. (D,E) Ventral and dorsal views of the same late middle divider. $\mathbf{( F , G ) ~ V e n t r a l ~ a n d ~ d o r s a l ~ v i e w s ~ o f ~ t h e ~ s a m e ~ m i d d l e - t o - l a t e ~ d i v i d e r . ~}(\mathbf{H}, \mathbf{I})$ Ventral and dorsal views of a new cell. DK, DK', proter's and opisthe's dorsal kineties; LA, LA', proter's and opisthe's lateral ciliary fields; LF, LF', proter's and opisthe's left ciliary fields; OP, oral primordium; RF, RF', proter's and opisthe's right ciliary fields; VK, VK', proter's and opisthe's ventral kineties. Scale bars: $20 \mu \mathrm{m}$. 


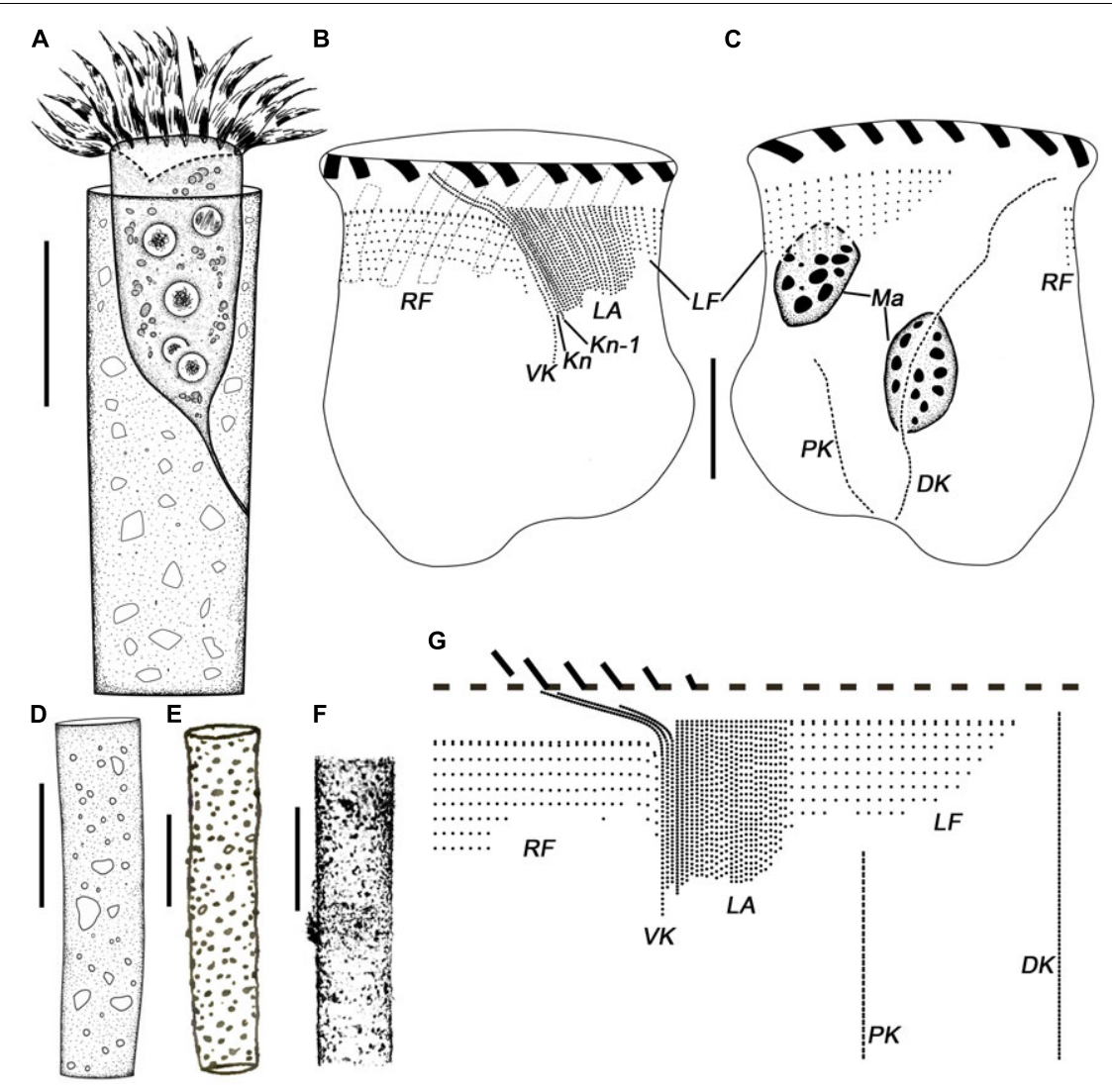

FIGURE 5 | Leprotintinnus simplex from life (A,D-F) and after protargol staining (B,C,G). (A) Lateral view of a typical individual. (B,C) The ciliary pattern of ventral and dorsal sides of the same specimen. (D) Loricae with agglomerated mineral particles. (E) Lateral view of loricae from Schmidt, 1902 . (F) L. neriticus from Yoo et al., 1988. (G) Kinetal map of a morphostatic specimen. DK, dorsal kinety; $K_{n}$, the last kinety of the lateral ciliary field; $K_{n-1}$, the penultimate kinety of the lateral ciliary field; LA, lateral ciliary field; LF, left ciliary field; Ma, macronuclear nodules; RF, right ciliary field; VK, ventral kinety. Scale bars: $40 \mu \mathrm{m}$ (A,D-F), $20 \mu \mathrm{m}$ (B,C).

specimens were deposited in the Laboratory of Protozoology, Ocean University of China, Qingdao, China.

\section{Morphological Description of Leprotintinnus simplex}

Lorica cylindrical, about $170-425 \mu \mathrm{m}$, gradually tapering $\left(2^{\circ}-\right.$ $4^{\circ}$ ) to the aboral end, and slightly curved in some individuals (Figures 5A,D, 6A-G and Table 1). Aperture 57-68 $\mu \mathrm{m}$ in diameter without an oral flare (Figures 5A,D, 6A-E). The ratio of length to opening diameter is 2.6-6.5:1. The aboral margin is often ragged, without a flare or a constriction, about 30$63 \mu \mathrm{m}$ across (Figures 5A,D, 6A-E). Wall comparatively thin, sparsely agglutinated with particles, about $2-10 \times 2-13 \mu \mathrm{m}$ in size (Figures 5D, 6G).

Naked live cells elongate doliform, usually $42-50 \times 40-$ $55 \mu \mathrm{m}$ in size (Figures $\mathbf{5 A}, \mathbf{6 F}$ and Table $\mathbf{1}$ ). After protargol staining, specimens about 45-130 $\times$ 47-65 $\mu \mathrm{m}$ in size. Two, rarely three, ellipsoidal macronuclear nodules centrally located in the cytoplasm, each about 10-35 × 9-22 $\mu \mathrm{m}$ in size, with nucleoli about $2 \mu \mathrm{m}$ across, anterior nodule 8-25 $\mu \mathrm{m}$ posteriorly to the anterior cell end (Figures 5C, 6H-J and Table 1). Micronuclei not recognized. Neither striae, tentaculoids, accessory combs, contractile vacuole, cytopyge, nor capsule was observed. Cytoplasm colorless and granular, with food vacuoles up to $5 \mu \mathrm{m}$ across containing yellow microalgae (Figure 6F). Slow swimming motion while rotating the main body cell axis. When picked and dropped onto clean glass slides in vivo, cells tend to escape from the loricae.

The somatic ciliary pattern of the most complex type (Agatha and Strüder-Kypke, 2007), i.e., comprising a ventral, a dorsal, and a posterior kinety as well as a right, a left, and a lateral ciliary field (Figures 5B,C,G, 6H-M and Table 1). Kinetids of each ciliary row ostensibly connected by argyrophilic fibers (Figures $6 \mathbf{H}$ M). Ventral kinety about 32-65 $\mu \mathrm{m}$ long, commencing about $1 \mu \mathrm{m}$ below the anterior end of the cell, anterior to the twelfth or thirteenth kinety of the right ciliary field, rarely anterior to the eighth or ninth one. Ventral kinety curving leftwards and extending parallel to kineties of the lateral ciliary field, and then terminated at the postmedian of cell proper, consisting of 48-84 ciliated monokinetids, which are closely spaced anterior but widely spaced posteriorly, cilium about $2 \mu \mathrm{m}$ long after impregnation (Figures 5B,G, 6H,J,L). The right ciliary field commences about $7-15 \mu \mathrm{m}$ posteriorly to the collar membranelles except for the first kinety (the leftmost 


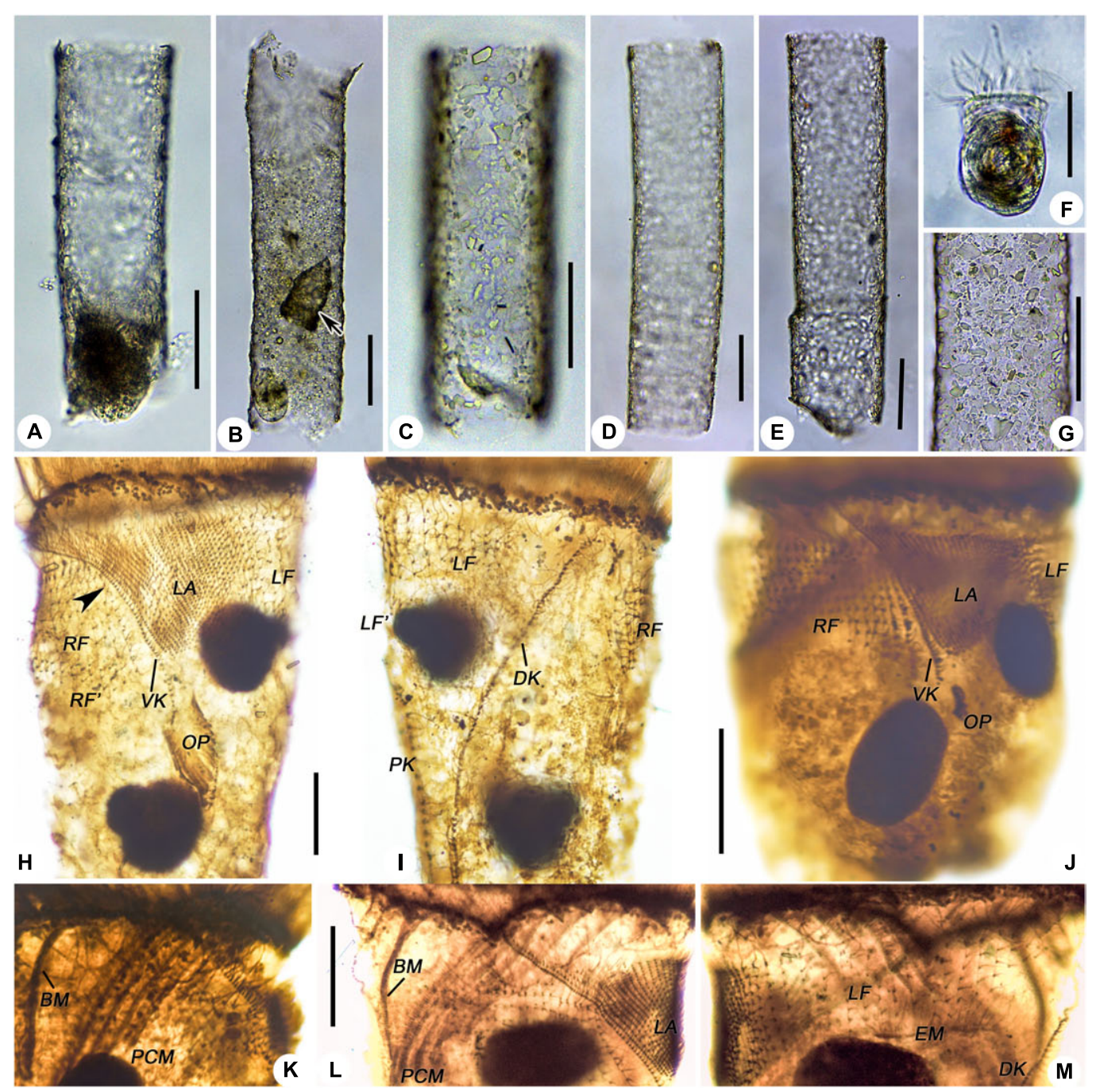

FIGURE 6 | Leprotintinnus simplex from life (A-G) and after protargol staining (H-M). (A) A representative specimen. (B-E) Showing the variability of loricae shape and size, the arrow denotes a predated Tintinnopsis sp. (F) Cell proper out of the lorica. (G) Lorica wall with numerous mineral particles. (H,I) Ventral and dorsal views of the same specimen, showing the ciliary pattern, arrowhead indicates the dikinetids at the anterior end of the right ciliary field. (J) Ventral view of an early divider, showing the location of the oral primordium and the posterior end of the VK. (K) Prolonged membranelles and buccal membranelle. (L) Lateral view showing the right ciliary filed and the anterior position of the VK; M, Left ciliary field, dorsal kinety, and endoral membranelle. BM, buccal membranelle; DK, dorsal kinety; EM, endoral membranelle; LA, lateral ciliary field; LF, LF', proter's and opisthe's left ciliary fields; OP, oral primordium; PCM, prolonged collar membranelles; RF, RF', proter's and opisthe's right ciliary field; VK, ventral kinety. Scale bars: $50 \mu \mathrm{m}$ (A-G), $15 \mu \mathrm{m}$ (H-M).

one), which commences about 10-25 $\mu$ m posterior to the collar membranelles. The kinety of the right ciliary field comprising 24-27 kineties, about 8-22 $\mu \mathrm{m}$ long, with a space about $2 \mu \mathrm{m}$, consisting of 4-12 monokinetids and one dikinetid anterior, the first kinety with two anterior dikinetids in a few specimens (Figures 5B,C,G, 6H-J,L). Cilia of the right ciliary field about 4-5 $\mu \mathrm{m}$ long after protargol impregnation and the anterior cilium of each dikinetids about 15-18 $\mu \mathrm{m}$ (Figures 6H-J,L). Dorsal kinety about 56-141 $\mu \mathrm{m}$ long, commencing about 2$5 \mu \mathrm{m}$ posterior to collar membranelles, about 7-20 $\mu \mathrm{m}$ apart from the left ciliary fields, and about 3-12 $\mu \mathrm{m}$ apart from the right ciliary fields, curving to the left and extending to the posterior end of cell proper, consisting of 61-103 dikinetids, with a cilium about 10-13 $\mu \mathrm{m}$ long (after protargol impregnation) on each posterior basal body (Figures 5C,G, 6I,M). The left ciliary field commencing about 3-8 $\mu \mathrm{m}$ posterior to collar membranelles, comprising 18-22 kineties, about 2-19 $\mu \mathrm{m}$ long, with a space about 2-3 $\mu \mathrm{m}$, consisting of 1-12 monokinetids and one anterior dikinetid, the first kinety often comprising of only one anterior dikinetid (Figures 5B,C,G, 6H,I,M). Cilia of the left ciliary field about $10 \mu \mathrm{m}$ long after protargol impregnation, and the anterior cilium of each dikinetids about $18 \mu \mathrm{m}$ (Figures $\mathbf{6 H}, \mathbf{I}, \mathbf{M}$ ). The lateral ciliary field commencing about 4-9 $\mu \mathrm{m}$ posteriorly to collar membranelles, except for (i) the last kinety $\left(\mathrm{K}_{n}\right)$ commencing close to the anterior end of the ventral kinety and extending parallel to the ventral kinety, 
and (ii) the penultimate kinety $\left(\mathrm{K}_{n-1}\right)$ commencing about 2$7 \mu \mathrm{m}$ posterior to collar membranelles, anterior to the fifth or sixth kinety of the right ciliary field, lower than the anterior end of $\mathrm{K}_{n}$ and higher than that of other kineties. The lateral ciliary field comprising 23-27 kineties, each kinety consisting of 9-14 densely spaced monokinetids about 11-20 $\mu \mathrm{m}$ long, excluding $\mathrm{K}_{n}$ and $\mathrm{K}_{n-1}$ which consist of 48-78 (28-59 $\mu \mathrm{m}$ long) and 4258 (30-54 $\mu \mathrm{m}$ long) densely spaced monokinetids, respectively. The monokinetid with a space about $1 \mu \mathrm{m}$; cilia about $6-\mu \mathrm{m}$ long after protargol impregnation (Figures 5B,G, 6H,J,L). Posterior kinety about 20-82 $\mu \mathrm{m}$ long, commencing about 13-35 $\mu \mathrm{m}$ posterior to the fifteenth (occasionally the thirteenth) kinety of the left ciliary field (about $18-50 \mu \mathrm{m}$ posterior to collar membranelles), and about 3-24 $\mu \mathrm{m}$ apart from the dorsal kinety, and extending almost longitudinally to the posterior end of cell proper, consisting of 19-40 dikinetids, with a cilium about 5$9 \mu \mathrm{m}$ long (after protargol impregnation) on each posterior basal body (Figures 5C,G, 6I).

Oral apparatus forming a closed circle at anterior cell end, 52-67 $\mu \mathrm{m}$ across after protargol staining, consisting of 1718 collar membranelles and invariably one buccal membranelle (Figures 5B,C,G, 6K and Table 1). Collar membranelles up to 23-55 $\mu \mathrm{m}$ long, separated by shallow ridges about $20 \mu \mathrm{m}$ wide, consisting of three rows of basal bodies, with cilia up to about 20$30 \mu \mathrm{m}$ long (Figures 5B, 6K). Polykinetids of the proximal-most five collar membranelles successively elongated, extending into the 30-35 $\mu \mathrm{m}$ deep buccal cavity (Figures 5B, 6K). Single buccal membranelle, with a base about 30-38 $\mu \mathrm{m}$ long (Figures 5B, 6K). Endoral membrane extending across the peristomial field and right side of the buccal cavity, composed of a single row of ciliated monokinetids (Figures 5B, 6K). Argyrophilic fibers were barely recognizable.

\section{Ontogenesis of Leprotintinnus simplex}

Only several individuals in cell division were stained. L. simplex shows an enantiotropic division mode as observed in several early and middle dividers. The hypoapokinetal somitogenesis occurred in a subsurface pouch located on the left of ventral kinety and posteriorly to the lateral ciliary field (Figures $\mathbf{6 H}-\mathbf{J}$ ).

\section{Sequences Comparison and Phylogenetic Analyses}

For the two species investigated, three nuclear rDNA markers (18S, ITS1-5.8S-ITS2, and 28S genes) and one mitochondrial marker ( $\mathrm{CO} 1$ gene) were sequenced. The sequences length, $\mathrm{G}+\mathrm{C}$ content, and GenBank accession numbers are shown in Table 2. Each of three rDNA sequences of $L$. nordqvisti in different aboral forms (with or without an aboral flare) were completely identical, respectively. Intraspecific genetic variations among individuals in the $\mathrm{CO} 1$ gene were $1.43 \%$ (7 nucleotide difference) and version $0.2 \%$ (1 nt) for L. nordqvisti and L. simplex, respectively. After removing the primers, the $18 \mathrm{~S}$ rDNA sequences of $L$. nordqvist newly obtained in this work differed by only one nucleotide (base deletion) from that of another population (KU715761) collected from the Jiaozhou Bay of Qingdao, China; however, its ITS1-5.8S rDNA-ITS2 (KU715800) was identical with that of our population (Zhang et al., 2017). As for L. simplex, the ITS1-5.8S-ITS2 and partial 28S rDNA sequences are available in the GenBank from a Jiaozhou Bay population. Sequence (KU715801) containing ITS1-5.8S-ITS2 and partial 28S rDNA is identical to the new sequence of $L$. simplex in this study. The sequence (KU715781) containing ITS2 and partial 28S rDNA differs from our population in the ITS2 region by one nucleotide (Zhang et al., 2017).

For each of these four markers, the topologies of both ML and BI trees are similar. So only the ML tree is shown. In the 18S rDNA tree, L. nordqvisti clusters with Tintinnopsis radix (KU715774, EU399540), and then form a full support clade with L. simplex. Tintinnopsis lobiancoi (JN831813), T. pseudocylindrica (JN831853), Stylicauda platensis (JN831832), Rhizodomus tagatzi (KU715762), Climacocylis scalaroides (KY290330), and C. scalaria (JQ408210) cluster together and form a sister group of Leprotintinnus-Tintinnopsis clade with nearly full support (99\% ML, 1 BI) (Figure 7). The topologies of the ITS and 28S rDNA trees are roughly consistent with that of 18 S rDNA-based analysis (Figures 7-9). L. simplex clusters with L. nordqvisti and T. radix (KU715816) clade with full support in the ITS rDNA tree (Figure 8). In the $28 \mathrm{~S}$ rDNA tree, L. nordqvisti and L. simplex clade is sister to the group of Rhizodomus tagatzi (KU715783), Tintinnopsis pseudocylindrica (KU831938), and Stylicauda platensis (JN831918) (Figure 9). In the CO1 tree, two sequences of $L$. nordqvisti cluster together, and then form a sister clade to the two sequences of $L$. simplex with weak support (56/0.98) (Figure 10).

\section{DISCUSSION}

\section{Comparison of Leprotintinnus nordqvisti With Other Populations}

Leprotintinnus nordqvisti was discovered for the first time from the Brazilian coast by Brandt (1906, 1907) named Tintinnus nordqvisti and then transferred to the genus Leprotintinnus by Kofoid and Campbell (1929) based on its lorica open at both ends. In the original report, this species was recorded as having an inverted funnel-shaped aboral flare, loricae length 105-200 $\mu \mathrm{m}$, opening diameter $30-45 \mu \mathrm{m}$, and posterior opening $40-60 \mu \mathrm{m}$ across (Brandt, 1906). Our population corresponds well with the original description, except for a slightly smaller posterior opening (28-45 $\mu \mathrm{m}$ vs. $40-60 \mu \mathrm{m}$ ) which might be caused by the absence of an aboral flare in some individuals of our population. In previous studies, the funnel-shaped aboral flare was regarded as the unique character for this species (Kofoid and Campbell, 1929). We found individuals with or without aboral flare in the same sample. In order to identify them, we extracted their DNA and performed the protargol impregnation separately for each individual with different lorica forms. The results combining both gene sequence (18S, ITS1-5.8S-ITS2, and 28S genes) and ciliary pattern verify that these individuals with or without the aboral flare are the same species. So, the identification of our population is solid. This study reveals the polymorphic loricae of L. nordqvisti for the first time. 
TABLE 2 | Gene sequences obtained in this study.

\begin{tabular}{|c|c|c|c|c|}
\hline Species (isolate type) & Marker & Length (bp) & GC content $(\%)$ & Accession number \\
\hline \multirow[t]{3}{*}{ Leprotintinnus nordqvisti (without an aboral flare) } & 18S rDNA & 1724 & 47.39 & OM131555 \\
\hline & ITS1-5.8S rDNA-ITS2 & 526 & 47.15 & \\
\hline & Partial 28S rDNA & 805 & 53.04 & \\
\hline \multirow[t]{4}{*}{ Leprotintinnus nordqvisti (without an aboral flare) } & $18 \mathrm{~S}$ rDNA & 1724 & 47.26 & OM131556 \\
\hline & ITS1-5.8S rDNA-ITS2 & 526 & 47.15 & \\
\hline & $28 \mathrm{~S}$ rDNA & 1755 & 50.31 & \\
\hline & CO1 & 478 & 39.75 & OM201658 \\
\hline \multirow[t]{4}{*}{ Leprotintinnus nordqvisti (with an aboral flare) } & $18 \mathrm{~S}$ rDNA & 1729 & 47.54 & OM131557 \\
\hline & ITS1-5.8S rDNA-ITS2 & 526 & 47.15 & \\
\hline & Partial 28S rDNA & 776 & 52.96 & \\
\hline & CO1 & 478 & 39.54 & OM201659 \\
\hline \multirow[t]{4}{*}{ Leprotintinnus simplex } & 18S rDNA & 1710 & 47.49 & OM131558 \\
\hline & ITS1-5.8S rDNA-ITS2 & 526 & 47.34 & \\
\hline & Partial 28S rDNA & 759 & 51.91 & \\
\hline & $\mathrm{CO1}$ & 478 & 41.21 & OM201660 \\
\hline Leprotintinnus simplex & CO1 & 478 & 41.42 & OM201661 \\
\hline
\end{tabular}

It is interesting that Sassi et al. (2004) reported a population of L. nordqvisti from neritic waters of Northeast Brazil and recorded that some loricae without the typical aboral dilatation common or with the dilatation little evident. Its loricae characters are in agreement with those of our population, i.e., lorica length (72.9-295.8 $\mu \mathrm{m}$ vs. 80-185 $\mu \mathrm{m})$, anterior opening diameter (31.2-43.7 $\mu \mathrm{m}$ vs. 37-46 $\mu \mathrm{m})$, and posterior opening across (23.2-122.9 $\mu \mathrm{m}$ vs. $28-45 \mu \mathrm{m})$. Our work confirms the speculation of Sassi et al. (2004).

Roxas (1941) also reported a population of tintinnids from the coast of Manila Bay and found some of the individuals with aboral flare but others without. Roxas (1941) identified the specimens with basal portion well expanded as L. nordqvisti (lorica length $118 \mu \mathrm{m}$, opening diameter $40 \mu \mathrm{m}$, posterior opening $78 \mu \mathrm{m}$ ) and those aboral end unexpanded as a new species, L. tubulosus Roxas (1941) (lorica length $140 \mu \mathrm{m}$, opening diameter $37 \mu \mathrm{m}$ ). In terms of loricae shape and size, L. tubulosus is identical to the specimens of $L$. nordqvisti without an aboral flare in our study. Therefore, L. tubulosus Roxas (1941) might be a synonym of L. nordqvisti.

The lorica with an aboral flare is unique to L. nordqvisti and can be easily distinguished from other tintinnids. This species had been reported many times in different seas (Table 3). The loricae length and opening diameters of these populations roughly coincide with those of our study, except for variations at the posterior flared portion.

\section{Comparison of Leprotintinnus nordqvisti With Related Species}

The typical lorica with a conspicuous funnel-shaped aboral flare makes L. nordqvisti to be distinguished easily from its congeners. Given that the aboral flare is now no longer a stable feature of L. nordqvisti, however, four similar congeners should be compared with $L$. nordqvisti, namely L. elongatus Skryabin and Al-Yamani, 2007, L. bubiyanicus Skryabin and Al-Yamani, 2007, L. neriticus (Campbell, 1926) Kofoid and Campbell, 1929, and L. simplex Schmidt, 1902.
Leprotintinnus elongatus is very similar with $L$. nordqvisti in lorica shape (tube-like lorica with slightly flaring oral and aboral ends vs. oral margin slightly flared and posterior end little widened in some individuals) and size of opening diameter (32.5$42.5 \mu \mathrm{m}$ vs. 37-46 $\mu \mathrm{m}$ ) (Skryabin and Al-Yamani, 2007). The loricae length of L. elongatus is significantly longer than that of L. nordqvisti (212.5-332.5 $\mu \mathrm{m}$ vs. 80-185 $\mu \mathrm{m})$, the measurement of its loricae length, however, likely included whole loricae with epilorica according to the illustrations given by Skryabin and Al-Yamani (2007). This implies that its actual length excluding epilorica would overlap with the range of $L$. nordqvisti in this study. In addition, according to Skryabin and Al-Yamani (2007), L. elongatus differed from L. nordqvisti by the absence of the aboral funnel. However, our study revealed the polymorphic loricae of $L$. nordqvisti, namely its aboral funnel might be absent in some individuals. So, L. elongatus and L. nordqvisti cannot be discriminated against by the aboral funnel. Therefore, $L$. elongatus is very likely to be a synonym of L. nordqvisti. Their relationship is pending further information on cytological and molecular data of L. elongatus.

Leprotintinnus nordqvisti differs from L. bubiyanicus and L. neriticus by its smaller opening diameter (37-46 $\mu \mathrm{m}$ in the former vs. $72.1-82.4 \mu \mathrm{m}$ in L. bubiyanicus, vs. $120-175 \mu \mathrm{m}$ in L. neriticus; Campbell, 1926; Skryabin and Al-Yamani, 2007). Leprotintinnus nordqvisti can be separated from L. simplex by the lorica shape (oral end flaring vs. never flaring), size (80$185 \mu \mathrm{m}$ vs.170-425 $\mu \mathrm{m}$ in length, and 37-46 $\mu \mathrm{m}$ vs. 57.5$67.5 \mu \mathrm{m}$ in opening diameter), and ciliary patterns (see below) (Schmidt, 1902).

\section{Occurrence and Ecology of Leprotintinnus nordqvisti}

The compilation is limited to L. nordqvisti and its synonym suggested above (see Table 3 ). Note that only some of them were substantiated by morphometric data and/or illustrations, therefore, misidentification cannot be excluded. 


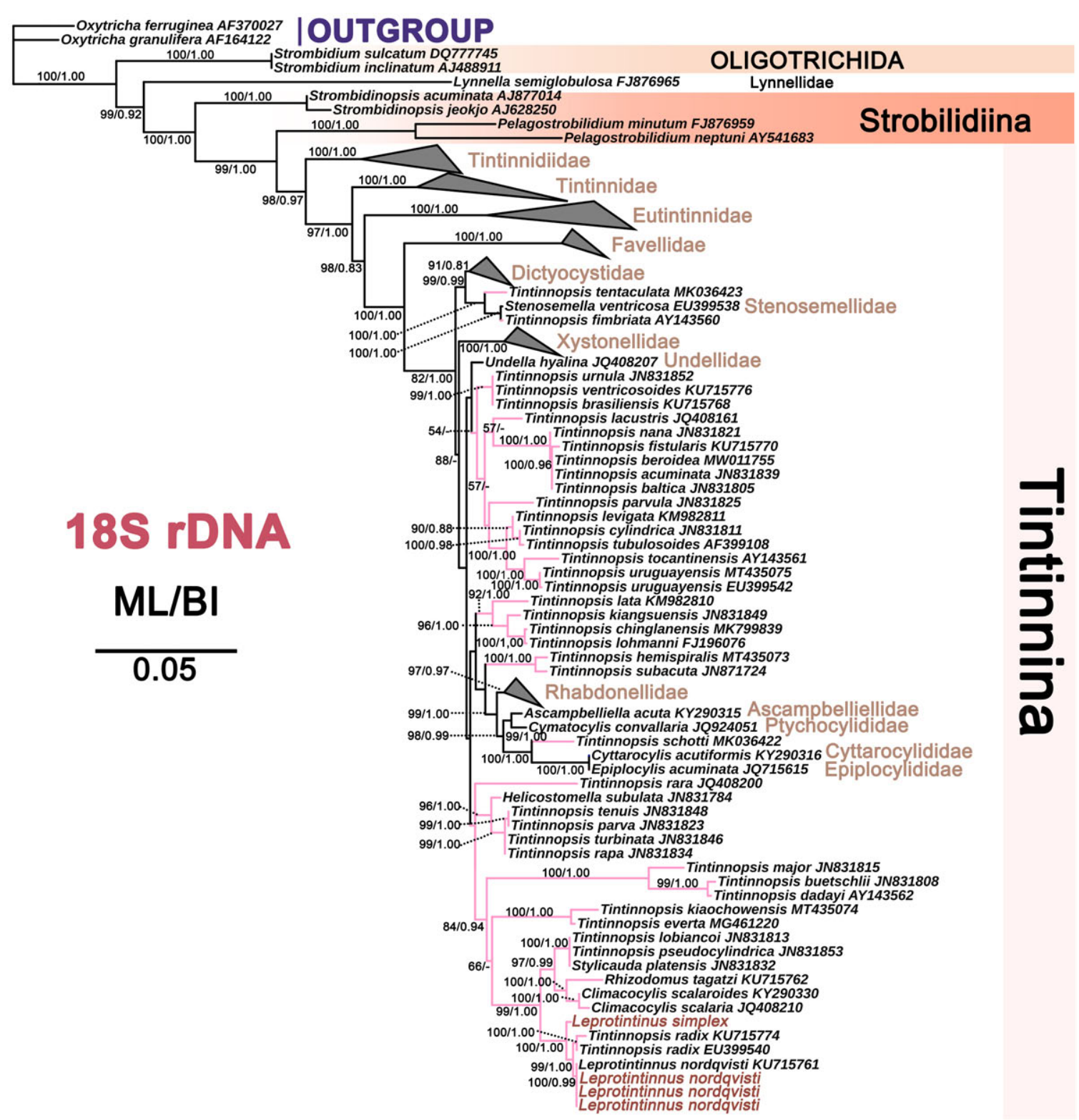

FIGURE 7|The maximum likelihood (ML) phylogenetic tree is inferred from 18S rDNA sequences. Numbers at the nodes represent support values in the following order: $\mathrm{ML}$ and $\mathrm{Bl}$ bootstrap values. The pink branch denotes the incertae sedis taxa in Tintinnina. The new sequences Leprotintinnus neriticus and $L$. simplex in the present work were indicated in red. A hyphen (-) represents support values too low $(\mathrm{ML}<45 \%, \mathrm{BI}<0.70)$ and disagreements in topology between the $\mathrm{Bl}$ and $\mathrm{ML}$ trees. The scale bar corresponds to 5 substitutions per 100 nucleotides.

According to Hada (1974), the species was found at a water temperature of about $29.1-29.5^{\circ} \mathrm{C}$, a salinity of about $28.38-$ $33.26 \%$, and a $\mathrm{pH}$ of about $7.9-8$, which were basically closed to the environmental factors in our study (salinity $27 \%, \mathrm{pH} 8.1$, and water temperature $23.5^{\circ} \mathrm{C}$ ). In Li et al. (2019), L. nordqvisti was considered as a brackish species, occurring at a salinity range of 9.2-34.1\%0. During winter and early spring, the abundance of L. nordqvisti was higher in Kuwait waters (Yousif Al-Yamani et al., 2011). A 10-year (May 2003 to December 2012) survey in Jiaozhou Bay, however, found that the species occurs in April, May, and July to October with a maximum abundance of $130 \mathrm{ind} / \mathrm{L}$ (Feng et al., 2018). Wang et al. (2014) recorded an abundance of.73 \pm 0.54 ind/L and biomass of $12.68 \pm 9.75 \mathrm{ng} \mathrm{C} / \mathrm{L}$ in the Northern Beibu Gulf, the South China Sea in August 2011.

\section{Comparison of Leprotintinnus simplex With Other Populations}

Leprotintinnus simplex originally found from the Gulf of Siam was recorded with a lorica $204 \mu \mathrm{m}$ long and the anterior opening $41 \mu \mathrm{m}$ across (Schmidt, 1902). Although the aboral diameter was not provided in the original description, it can be inferred 


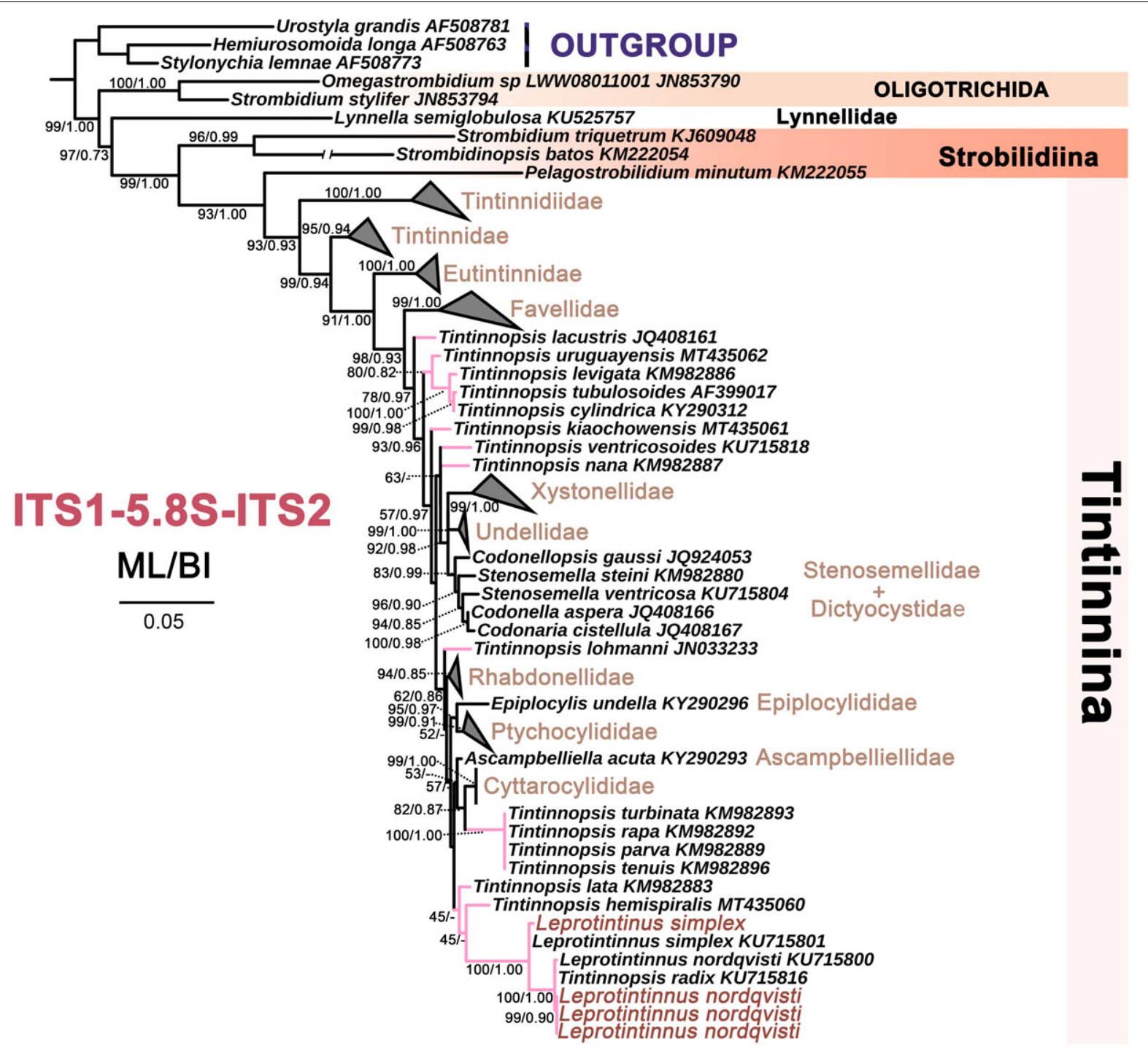

FIGURE 8 | The maximum likelihood (ML) phylogenetic tree is inferred from ITS1-5.8S rDNA-ITS2 sequences. Numbers at the nodes represent support values in the following order: ML and BI bootstrap values. The pink branch denotes the incertae sedis taxa in Tintinnina. The new sequences Leprotintinnus neriticus and L. simplex in the present work were indicated in red. A hyphen $(-)$ represents support values too low $(\mathrm{ML}<45 \%, \mathrm{BI}<0.70)$ and disagreements in topology between the $\mathrm{BI}$ and $\mathrm{ML}$ trees. The scale bar corresponds to 5 substitutions per 100 nucleotides.

from the single illustration as about $35 \mu \mathrm{m}$. Our population corresponds well with the original description in terms of lorica shape (cylindrical or subcylindrical lorica) and length (170$425 \mu \mathrm{m}$ vs. $204 \mu \mathrm{m}$ ), although there are slight differences in the opening diameter of the anterior end (57-68 $\mu \mathrm{m}$ vs. $41 \mu \mathrm{m})$ and the aboral end (30-63 $\mu \mathrm{m}$ vs. about $35 \mu \mathrm{m})$, which might be caused by different amount of loricae that measured or the difference among populations. So, our population was finally identified as L. simplex Schmidt (1902). This identification was supported by the population of Zhang et al. (2017), which was reported having similar lorica length (175 $\mu \mathrm{m}$ vs. $170-425 \mu \mathrm{m})$ with our population and similar opening diameter $(42 \mu \mathrm{m}$ vs. $41 \mu \mathrm{m}$ ) with the original population. What's more, the population of Zhang et al. (2017) had almost identical ITS and partial $28 \mathrm{~S}$
rDNA sequences with those of our population. So, Zhang et al. (2017) help to confirm our species identification.

The study of Yoo et al. (1988) described a tintinnid species, Leprotintinnus neriticus in Chinhae Bay in November 1981. Its lorica characters are significantly different from the original description of this species, i.e., lorica length (320-430 $\mu \mathrm{m}$ vs. 380-470 $\mu \mathrm{m}$ ), opening diameter (60 $\mu \mathrm{m}$ vs. 120-175 $\mu \mathrm{m}$ ), aboral diameter (50-55 $\mu \mathrm{m}$ vs. 90-172 $\mu \mathrm{m}$ ) (Campbell, 1926). However, the population of Yoo et al. (1988) matches perfectly with our population in terms of the lorica shape (simple, tubular lorica vs. cylindrical lorica), length (320-430 $\mu \mathrm{m}$ vs. 170$425 \mu \mathrm{m})$, opening diameter (60 $\mu \mathrm{m}$ vs. 57-68 $\mu \mathrm{m})$, and aboral diameter (50-55 $\mu \mathrm{m}$ vs. 30-63 $\mu \mathrm{m})$. It is noteworthy that, in Yoo et al. (1988), a population of L. simplex with lorica length 


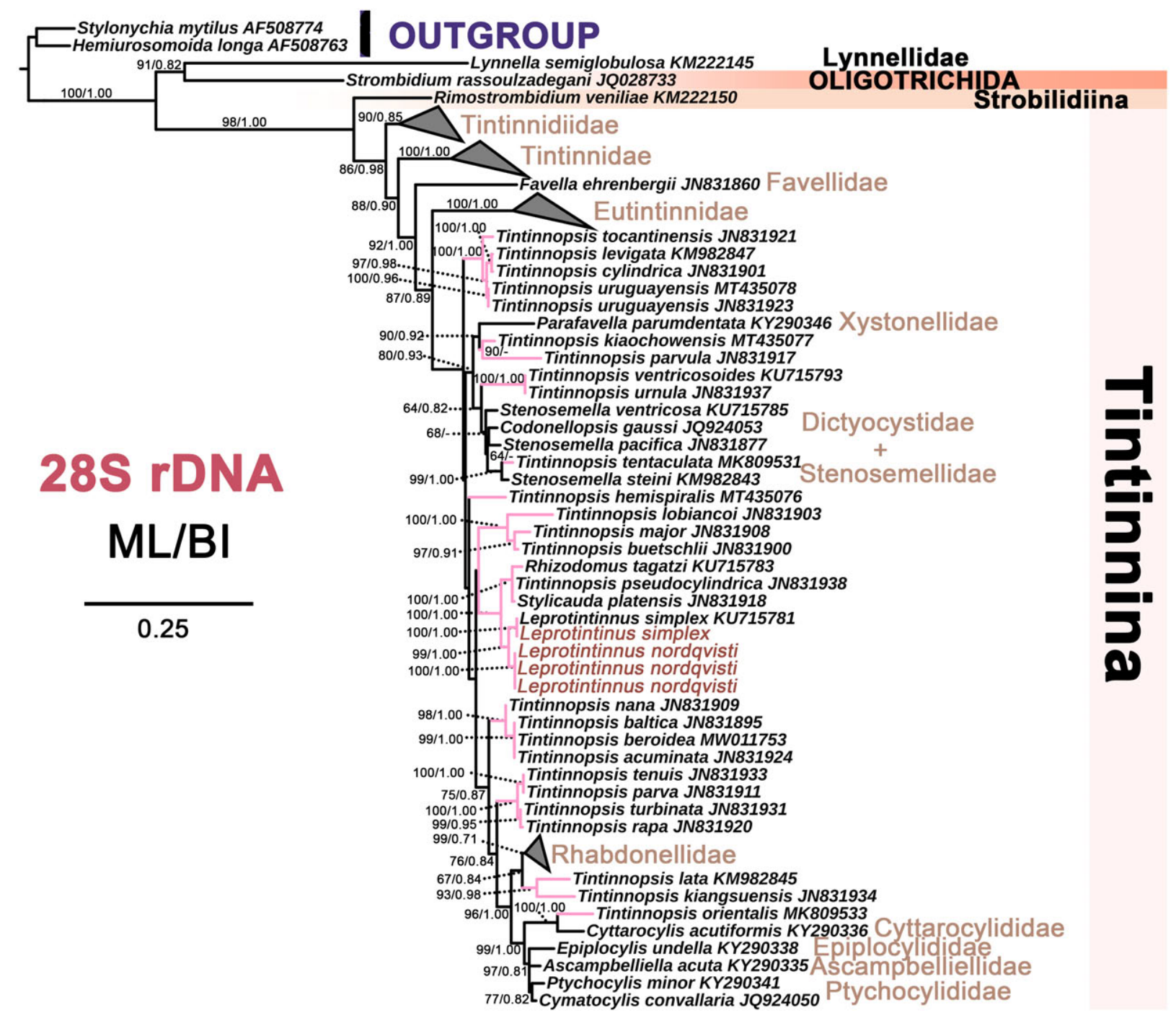

FIGURE 9 | The maximum likelihood (ML) phylogenetic tree is inferred from $28 \mathrm{~S}$ rDNA sequences. Numbers at the nodes represent support values in the following order: $\mathrm{ML}$ and $\mathrm{Bl}$ bootstrap values. The pink branch denotes the incertae sedis taxa in Tintinnina. The new sequences Leprotintinnus neriticus and $L$. simplex in the present work were indicated in red. A hyphen (-) represents support values too low $(\mathrm{ML}<45 \%, \mathrm{BI}<0.70)$ and disagreements in topology between the $\mathrm{Bl}$ and $\mathrm{ML}$ trees. The scale bar corresponds to 25 substitutions per 100 nucleotides.

$200 \mu \mathrm{m}$ and opening diameter of $38 \mu \mathrm{m}$ was also found from the same site with its $L$. neriticus population. Therefore, L. neriticus sensu Yoo et al. (1988) might be a misidentification of L. simplex.

Leprotintinnus simplex had also been recorded from western tropical Pacific with lorica length $205 \mu \mathrm{m}$ and opening diameter of $38 \mu \mathrm{m}$ (Hada, 1938), coastal waters of Qingdao with lorica length 250-360 $\mu \mathrm{m}$ and opening diameter 50-60 $\mu \mathrm{m}$ (Xu and Song, 2005), Chilika Lagoon with lorica length $297.32 \mu \mathrm{m}$ and opening diameter $58.19 \mu \mathrm{m}$ (Mukherjee et al., 2015), Jiaozhou Bay, China with lorica length $175 \mu \mathrm{m}$ and opening diameter $42 \mu \mathrm{m}$ (Zhang et al., 2017), and coastal waters of Xiamen with lorica length 340-415 $\mu \mathrm{m}$ and opening diameter 61-67 $\mu \mathrm{m}$ (Liao et al., 2018). The loricae length and opening diameters of all above populations roughly coincide with our population (lorica length 170-425 $\mu \mathrm{m}$, opening diameter 57-68 $\mu \mathrm{m}$ ) and original description (lorica $204 \mu \mathrm{m}$ long and the anterior opening $41 \mu \mathrm{m}$ across) of L. simplex (Table 3).

\section{Comparison of Leprotintinnus simplex With Related Species}

The four Leprotintinnus species are similar to L. simplex by their cylindrical or subcylindrical lorica without sharp narrowing of the aboral end, namely L. nordqvisti (Brandt, 1906) Kofoid and Campbell, 1929, L. bubiyanicus Skryabin and Al-Yamani, 2007, L. elongatus Skryabin and Al-Yamani, 2007, and L. neriticus (Campbell, 1926) Kofoid and Campbell, 1929. L. simplex can be distinguished out by its smaller anterior opening $(57-68 \mu \mathrm{m})$ from L. bubiyanicus (vs. 72.1-82.4 $\mu \mathrm{m}$ ) and L. neriticus (vs. 120-175 $\mu \mathrm{m}$ ) (Campbell, 1926; Skryabin and Al-Yamani, 2007). 


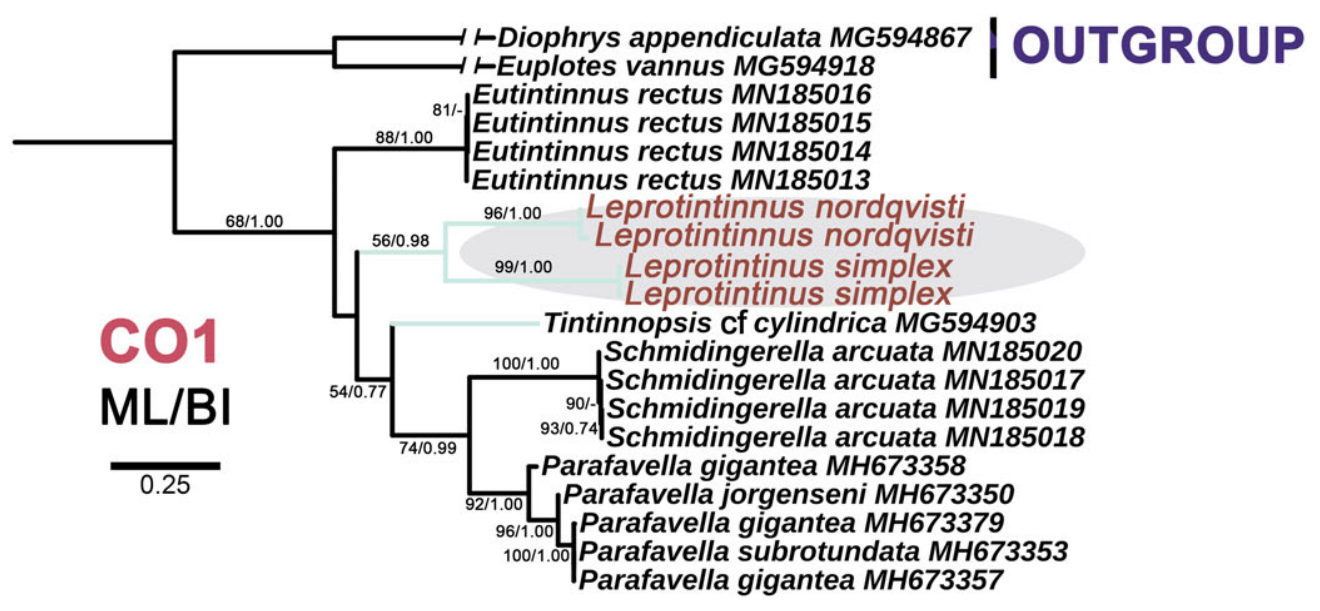

FIGURE 10 | The maximum likelihood (ML) phylogenetic tree is inferred from CO1 gene sequences. Numbers at the nodes represent support values in the following order: $\mathrm{ML}$ and $\mathrm{BI}$ bootstrap values. The green branch denotes the incertae sedis taxa in Tintinnina. The new sequences $L$ eprotintinnus neriticus and $L$. simplex in the present work were indicated in red. A hyphen (-) represents support values too low ( $\mathrm{ML}<45 \%, \mathrm{BI}<0.70)$ and disagreements in topology between the Bl and $\mathrm{ML}$ trees. The scale bar corresponds to 25 substitutions per 100 nucleotides.

L. simplex differs from L. elongatus by the absence of the flaring oral end (Skryabin and Al-Yamani, 2007).

Leprotintinnus nordqvisti and L. simplex are the only two species with known ciliary patterns in the genus at present. Both species have very similar cell features, but can be distinguished from each other by the starting position of the ventral kinety (anteriorly to the fifth or sixth kinety of the right ciliary field in the former vs. to the twelfth or thirteenth kinety of the right ciliary field) and kinety numbers of the right (13-15 vs. 24-27), left (10-12 vs. 18-22), and lateral (16-19 vs. 23-27) ciliary field.

\section{Occurrence and Ecology of Leprotintinnus simplex}

The compilation is limited to $L$. simplex populations (see Table 3). Note that only some of them were substantiated by morphometric data and/or illustrations, therefore, misidentification cannot be excluded.

In the study of Li et al. (2019), L. simplex was considered as a brackish species, occurring at a salinity range of $11.8-34.1 \%$. A 10-year (May 2003 to December 2012) survey in Jiaozhou Bay, found that the species excluding May were present with a maximum abundance of 130 ind/L (Feng et al., 2018). In August 2011, Wang et al. (2014) recorded an abundance of $20.63 \pm 11.09$ ind/L and biomass of $161.60 \pm 74.14 \mathrm{ng} \mathrm{C} / \mathrm{L}$ in the Northern Beibu Gulf, South China Sea.

\section{Ontogenesis of Leprotintinnus in Tintinnids}

The cell division of Leprotintinnus matches that previously reported species with a complex somatic ciliary pattern in the position of the oral primordium (e.g., Petz and Foissner, 1993; Laval-Peuto, 1994; Agatha and Riedel-Lorjé, 2006; Agatha and Tsai, 2008; Gruber et al., 2018). In these reports, it appears that the dorsal and posterior kineties of the daughter cells are broken from old (parental) structures, as the right side of the old structures does not develop basal body proliferation. However, only in Tintinnopsis everta was reported a late middle divider showing the splits of dorsal and posterior kineties, which differs from the de novo proliferation that we reported in the present study. Unfortunately, we failed to observe the separation of dorsal and posterior kineties in the very late stages of ontogenesis. We speculate that the kineties position of the opisthe is asymmetrical to the proter due to the breakage of the argyrophilic fibers in the very late stages of cell division, with the left ciliary field of the opisthe closer to the right than that in the proter. Through this gap, the posterior and dorsal kineties of the proter gradually move upwards as the cell body extends and rotates, while the posterior and dorsal kineties of the opisthe gradually move downwards. Finally, the proter and opisthe separate, acquiring the old and new structures, respectively.

\section{The Ciliary Pattern of Leprotintinnus in Tintinnids}

This study reveals that the ciliary pattern of the genus Leprotintinnus is attributed to the most complex type, which consists of a ventral, a dorsal, and a posterior kinety as well as a right, a left, and a lateral ciliary field (Agatha and StrüderKypke, 2007). This type of ciliary pattern has been reported in many other genera, such as Codonlla (affiliation doubtful) (Foissner et al., 1999), Codonellopsis (Petz et al., 1995; Kim et al., 2013), Laackmanniella (Kim et al., 2013), Cymatocylis (Wasik and Mikolajczyk, 1994; Petz et al., 1995), Stenosemella (Agatha and Tsai, 2008), Tintinnopsis (Gruber et al., 2018), and Schmidingerella (Agatha and Strüder-Kypke, 2012). The differences in the ciliary patterns of these species are very slight, except for the position of the posterior kinety is shifty. At present, it is still difficult to distinguish different families or genera by this type of ciliary pattern. We can only help future taxonomic revise by reporting more cell features that reveal new patterns of 
TABLE 3 | Morphology and distribution of reported populations of Leprotintinnus nordqvisti and L. simplex.

\begin{tabular}{|c|c|c|c|c|c|}
\hline Species & Location & Lorica length $(\mu \mathrm{m})$ & $\begin{array}{l}\text { Anterior aperture } \\
\text { diameter }(\mu \mathrm{m})\end{array}$ & $\begin{array}{l}\text { Posterior opening diameter } \\
\qquad(\mu \mathrm{m})\end{array}$ & Ref. \\
\hline \multirow[t]{4}{*}{ L. nordqvisti } & Coast of Brazilian & $105-200$ & $30-45$ & $40-60$ & Brandt, 1906 \\
\hline & Bay of Amoy & 200 & $\begin{array}{l}\text { about six times the oral } \\
\text { diameter in length }\end{array}$ & - & Wang and Nie, 1932 \\
\hline & Tropical Pacific & $150-352$ & $30-38$ & $40-80$ & Hada, 1938 \\
\hline & Coast of Manila Bay & 118 & 40 & 78 & Roxas, 1941 \\
\hline \multirow{18}{*}{$\begin{array}{l}\text { L. tubulosus } \\
\text { (original name) }\end{array}$} & Coast of Manila Bay & 140 & 37 & - & Roxas, 1941 \\
\hline & Gulf of California & 144 & 43 & 66 & Osorio-Tafall, 1941 \\
\hline & Arabian Sea Coast of India & $125-270$ & $37-43$ & $30-33$ & Hada, 1974 \\
\hline & Chinhae Bay & $135-240$ & $33-38$ & $48-83$ & Yoo et al., 1988 \\
\hline & Uranouchi Inlet & $108-223$ & $33-44$ & 56-95 & Nakamachi and Iwasaki, 1998 \\
\hline & Subtropical waters of the Southern Brazil & $154-215$ & 38-39 & $45-75$ & Fernandes, 2004 \\
\hline & Coast of Brazilian & 72.9-295.8 & $31.2-43.7$ & $23.2-122.9$ & Sassi et al., 2004 \\
\hline & Kuwait Waters & 128-192 & $43 \pm 1$ & 109-154 & Yousif Al-Yamani et al., 2011 \\
\hline & Coastal waters off Guangdong & 200 & 40 & 80 & Zhang et al., 2012 \\
\hline & The Northern Beibu Gulf & - & - & - & Wang et al., 2014 \\
\hline & Chilika Lagoon & 180 & 41.71 & 83.87 & Mukherjee et al., 2015 \\
\hline & Jiaozhou Bay & 156 & 45 & - & Zhang et al., 2017 \\
\hline & Coast of Manila Bay & $182-243$ & $36-49$ & - & Santiago et al., 2017 \\
\hline & The coastal zone of India & - & - & - & Elangovan and Gauns, 2018 \\
\hline & Jiaozhou Bay & - & - & - & Feng et al., 2018 \\
\hline & The Pearl River Estuary in southern China & - & - & - & Li et al., 2019 \\
\hline & The North Western Coast of the Red Sea & - & - & - & Saber et al., 2021 \\
\hline & An oyster farm of Yanjiang & $80-185$ & $37-46$ & $28-45$ & Present work \\
\hline \multirow[t]{4}{*}{ L. simplex } & Gulf of Siam & 204 & 41 & - & Schmidt, 1902 \\
\hline & Western tropical Pacific & 205 & 38 & - & Hada, 1938 \\
\hline & Hiroshima Bay & - & - & - & \\
\hline & Chinhae Bay & 200 & 38 & - & Yoo et al., 1988 \\
\hline \multirow{10}{*}{$\begin{array}{l}\text { Original name } \\
\text { L. neriticus }\end{array}$} & Chinhae Bay & $320-430$ & 60 & $50-55$ & Yoo et al., 1988 \\
\hline & Coastal waters off Qingdao & $250-360$ & $50-60$ & - & Xu and Song, 2005 \\
\hline & The Northern Beibu Gulf & - & - & - & Wang et al., 2014 \\
\hline & Chilika Lagoon & 297.32 & 58.19 & - & Mukherjee et al., 2015 \\
\hline & Jiaozhou Bay & 175 & 42 & - & Zhang et al., 2017 \\
\hline & The coastal zone of India & - & - & - & Elangovan and Gauns, 2018 \\
\hline & Jiaozhou Bay & - & - & - & Feng et al., 2018 \\
\hline & Coastal waters off Amoy & $340-415$ & $61-67$ & - & Liao et al., 2018 \\
\hline & The Pearl River Estuary in southern China & - & - & - & Li et al., 2019 \\
\hline & Yundang Lake of Amoy & $170-425$ & $57-68$ & $30-63$ & Present work \\
\hline
\end{tabular}

,- Null value.

somatic ciliature or some subtle but very important features in the most complex ciliature pattern (Agatha and Strüder-Kypke, 2012; Gruber et al., 2018).

Tintinnopsis radix (Imhof, 1886) Brandt, 1907 and Rhizodomus tagatzi Strelkow and Wirketis, 1950 are the most similar tintinnid species to L. nordqvisti and L. simplex based on their common ciliary pattern, i.e., the ventral kinety curving drastically to the right and extending anterior to the right ciliary field, and the posterior kinety positioned below the left ciliary field (Jiang et al., 2012; Saccà et al., 2012). These four species can be distinguished by each other by the complexity of different numbers of kineties. In addition, $L$. nordqvisti and $L$. simplex can be distinguished from $T$. radix and $R$. tagatzi by the position of the anterior end of the rightmost two lateral kineties. It should not be omitted that $R$. tagatzi in Saccà et al. (2012), the dorsal kinety of it composed of monokinetids, which is significantly different from Leprotintinnus. Naturally, without electron microscopic studies, it cannot be excluded that the dorsal kinety consists indeed of dikinetids with only one basal body ciliated and that the unciliated basal body was not recognized due to insufficient staining. 
Bai et al. (2020) reported Tintinnopsis cf. radix with a very similar ciliary pattern to Leprotintinnus, namely both the ventral kinety and the rightmost two lateral kineties largely curved above the kinety of the right ciliary field from photomicrographs. However, the posterior kinety of the former commences below the ventral kinety (vs. below the left ciliary field for Leprotintinnus). The taxonomic significance of the position of the posterior kinety at the genus or family level is still unclear. Bai et al. (2020) did not provide any molecular data of Tintinnopsis cf. radix. Therefore, its relationship with Leprotintinnus is pending.

Leprotintinnus nordqvisti and L. simplex are also similar with Tintinnopsis everta in the significant anterior extending of the ventral kinety and the last lateral kinety, however, the latter can be separated from them by the position of the anterior end of the ventral and the rightmost two lateral kineties (see below). Gruber et al. (2018) had assumed that the evolution of the ventral kinety might gradually be curving rightward, extending anterior to the kinety of the right ciliary field, simultaneously with a parallel extension of the last kinety of the lateral ciliary field. Considering that the anterior end of the ventral and the rightmost two lateral kineties in $L$. nordqvisti and L. simplex extending further than that of T. everta, L. nordqvisti, and L. simplex may provide a later stage than $T$. everta in the evolution of the ventral kinety reconstruction.

\section{Phylogeny of Leprotintinnus in Tintinnids}

Our phylogeny analyses show that Leprotintinnus species cluster with Tintinnopsis radix with full support, and then form a big clade with some species of Tintinnopsis, Stylicauda, Rhizodomus, and Climacocylis with nearly full support. This result is consistent with some previous reports (Santoferrara et al., 2017). In terms of loricae features, the genera Tintinnopsis, Leprotintinnus, Rhizodomus, and Stylicauda differ from Climacocylis by having the sparsely agglutinated loricae (vs. hyaline loricae in Climacocylis). This is apparently inconsistent with the phylogenetic relationship shown in the molecular trees. Therefore, all these genera were assigned to incertae sedis in Tintinnina (Santoferrara et al., 2017; Zhang et al., 2017). The species with available ciliary patterns in this phylogeny clade, i.e., L. nordqvisti, L. simplex, T. radix, and $R$. tagatzi display high similarities in terms of their cytological features (Saccà et al., 2012). This agrees with the phylogeny results and

\section{REFERENCES}

Adl, S. M., Bass, D., Lane, C. E., Lukes, J., Schoch, C. L., Smirnov, A., et al. (2019). Revisions to the classification, nomenclature, and diversity of Eukaryotes. J. Eukaryot. Microbiol. 66, 4-119. doi: 10.1111/jeu.12691

Agatha, S., and Bartel, H. (2021). A comparative ultrastructural study of tintinnid loricae (Alveolata, Ciliophora, Spirotricha) and a hypothesis on their evolution. J. Eukaryot. Microbiol. Online ahead of print. doi: 10.1111/jeu.12877

Agatha, S., and Riedel-Lorjé, J. C. (2006). Redescription of Tintinnopsis cylindrica Daday, 1887 (Ciliophora : Spirotricha) and unification of tintinnid terminology. Acta Protozool. 45, 137-151.

Agatha, S., and Strüder-Kypke, M. C. (2007). Phylogeny of the order Choreotrichida (Ciliophora, Spirotricha, Oligotrichea) as inferred from morphology, ultrastructure, ontogenesis, and SSrRNA gene sequences. Eur. J. Protistol. 43, 37-63. doi: 10.1016/j.ejop.2006.10.001 suggests their homologous evolution in morphology. However, considering that most ciliary patterns in this clade have not been revealed yet, the taxonomic data are still not enough to revise the classification of the species contained in this branch. Nevertheless, we can speculate that the large anterior extending of the ventral kinety together with the last or penultimate lateral kinety is likely to be a promising distinguishing feature of this clade or genus of Leprotintinnus. Also, given that most of the loricae in this clade are sparse agglutination, they likely represent a homology in the wall ultrastructure or lorica matrix material (Agatha and Bartel, 2021).

\section{DATA AVAILABILITY STATEMENT}

The datasets presented in this study can be found in online repositories. The names of the repository/repositories and accession number(s) can be found below: NCBI [accession: OM131555-OM131558 and OM201658-OM201661].

\section{AUTHOR CONTRIBUTIONS}

XL conceived and directed the research. TH and ZW performed the sampling and conducted the taxonomic and phylogenetic work. $\mathrm{TH}$ and $\mathrm{WL}$ identified the species. $\mathrm{TH}$ drafted the manuscript. ZW, WL, and XL made further revisions. All authors approved the submitted version of manuscript.

\section{FUNDING}

This work was supported by the projects of the National Natural Science Foundation of China (42076113 and 31761133001) and the Fundamental Research Funds for the Central Universities (20720200106).

\section{ACKNOWLEDGMENTS}

Many thanks are due to Sabine Agatha for her kindly helping to provide important literature Campbell (1926).

Agatha, S., and Strüder-Kypke, M. C. (2012). Reconciling cladistic and genetic analyses in Choreotrichid ciliates (Ciliophora, Spirotricha, Oligotrichea). J. Eukaryot. Microbiol. 59, 325-350. doi: 10.1111/j.1550-7408.2012.00 623.x

Agatha, S., and Tsai, S.-F. (2008). Redescription of the tintinnid Stenosemella pacifica Kofoid and Campbell, 1929 (Ciliophora, Spirotricha) based on live observation, protargol impregnation, and scanning electron microscopy. J. Eukaryot. Microbiol. 55, 75-85. doi: 10.1111/j.1550-7408.2008.00309.x

Bai, Y., Wang, R., Song, W., Suzuki, T., and Hu, X. Z. (2020). Redescription of five tintinnine ciliates (Alveolata: Ciliophora: Oligotrichea) from coastal waters of Qingdao. China. Mar. Life Sci. Technol. 2, 209-221. doi: 10.1007/s42995-02000034-32

Brandt, K. A. H. (1906). Die Tintinnodeen der Plankton-Expedition. Tafelerklarungen Nebst Kurzer Diagnose der Neuen Arten. Kiel: Lipsius \& Tischer. 
Brandt, K. A. H. (1907). "Die tintinnodeen der plankton-expedition. systematischer teil," in Ergebnisse der Plankton-Expedition der Humboldt-Stiftung 3 La, ed. V. Hensen (Kiel: Lepsius and Tischer).

Campbell, A. S. (1926). On Tintinnus neriticus sp. nov., from San Francisco bay. Univ. Calif. Publ. Zool. 29, 237-239.

Cleve, P. T. (1899). Plankton collected by the Swedish expedition to Spitzbergen in 1898. Kongl. Sven. Vetensk. Akad. Handl. 32, 1-51.

Corliss, J. O. (2003). Comments on the neotypification of protists, especially ciliates (Protozoa, Ciliophora). Bull. Zool. Nom. 60, $48-48$.

Dolan, J. R. (2016). Planktonic protists: little bugs pose big problems for biodiversity assessments. J. Plankton Res. 38, 1044-1051. doi: 10.1093/plankt/ fbv079

Dolan, J. R., Montagnes, D. J., Agatha, S., Coats, D. W., and Stoecker, D. K. (2013). The Biology and Ecology of Tintinnid Ciliates: Models for Marine Plankton. Wiley-Blackwell: Oxford.

Elangovan, S. S., and Gauns, M. (2018). A checklist of tintinnids (loricate ciliates) from the coastal zone of India. Environ. Monit. Assess. 190, 1-18. doi: 10.1007/ s10661-018-7039-y

Feng, M., Wang, C., Zhang, W., Zhang, G., Xu, H., Zhao, Y., et al. (2018). Annual variation of species richness and lorica oral diameter characteristics of tintinnids in a semi-enclosed bay of western Pacific. Estuar. Coast. Shelf S. 207, 164-174. doi: 10.1016/j.dib.2018.06.010

Fernandes, L. F. (2004). Tintinnids (Ciliophora, Tintinnina) from subtropical waters of the Southern Brazil. I. families codonellidae, codonellopsidae, coxliellidae, cyttarocylidae, epiplocylidae, petalotrichidae, ptychocylidae, tintinnididae and undellidae. Rev. Bras. Zool. 21, 551-576. doi: 10.1590/s0101-81752004000300019

Foissner, W. (2002). Neotypification of protists, especially ciliates (Protozoa, Ciliophora) Wilhelm Foissner. Bull. Zool. Nom. 59:165.

Foissner, W., and O'Donoghue, P. J. (1990). Morphology and infraciliature of some freshwater ciliates (Protozoa: Ciliophora) from Western and South Australia. Invertebr. Syst. 3, 661-696. doi: 10.1071/it9890661

Foissner, W., Berger, H., and Schaumburg, J. (1999). Identification and Ecology of Limnetic Plankton Ciliates. München: Bartels \& Wemitz.

Gold, K., and Morales, E. A. (1974). Effects of temperature on 2 strains of Tintinnopsis tubulosa. J. Protozool. 21, 442-442.

Gold, K., and Morales, E. A. (1975). Tintinnida of the New York Bight: loricae of Parafavella gigantea, P. parumdentata, and Ptychocylis obtusa. Trans. Am. Microsc. Soc. 94, 142-145.

Gruber, M. S., Strüder-Kypke, M., and Agatha, S. (2018). Redescription of Tintinnopsis everta Kofoid and Campbell, 1929 (Alveolata, Ciliophora, Tintinnina) based on taxonomic and genetic analyses-discovery of a new complex ciliary pattern. J. Eukaryot. Microbiol. 65, 484-504. doi: 10.1111/jeu. 12496

Hada, Y. (1938). Studies on the Tintinnoinea from the Western Tropical Pacific (with 3 tables and 100 textfigures). J. Fac. Sci., Hokkaido Univ. Ser. 6, 87-190.

Hada, Y. (1974). The protozoan plankton collected from the port of Cochin on the Arabian Sea coast of India. Univ. Liter. 15, 73-97.

Imhof, O. E. (1886). Über microscopische pelagische Thiere aus den Lagunen von Venedig. Zool. Anz. 9, 101-104.

International Code of Zoological Nomenclature [ICZN] (1999). International Code of Zoological Nomenclature: International Commission on Zoological Nomenclature. London: London International Trust for Zoological Nomenclature.

Jerome, C. A., Lynn, D. H., and Simon, E. M. (1996). Description of Tetrahymena empidokyrea n. sp., a new species in the Tetrahymena pyriformis sibling species complex (Ciliophora, Oligohymenophorea), and an assessment of its phylogenetic position using small-subunit rRNA sequences. Can. J. Zool. 74, 1898-1906.

Ji, D. D., and Wang, Y. F. (2018). An optimized protocol of protargol staining for ciliated protozoa. J. Eukaryot. Microbiol. 65, 705-708. doi: 10.1111/jeu.12515

Jiang, Y., Yang, J. P., Al-Farraj, S. A., Warren, A., and Lin, X. F. (2012). Redescriptions of three tintinnid ciliates, Tintinnopsis tocantinensis, T. radix, and T. cylindrica (ciliophora, spirotrichea), from coastal waters off China. Eur. J. Protistol. 48, 314-325. doi: 10.1016/j.ejop.2012.02.001

Jörgensen, E. (1900). Ueber die Tintinnodeen der norwegischen Westktüste. Bergens Museums Aarbog. 1899, 1-48.
Jörgensen, E. (1901). Protistenplankton aus dem Nordmeere in den Jahren 18971900. Bergens Mus. Aarbog 1900 1-37. doi: 10.1515/9783112383629-003

Kalyaanamoorthy, S., Minh, B. Q., Wong, T. K., von Haeseler, A., and Jermiin, L. S. (2017). ModelFinder: fast model selection for accurate phylogenetic estimates. Nat. Methods 14, 587-589. doi: 10.1038/nmeth. 4285

Katoh, K., and Standley, D. M. (2013). MAFFT multiple sequence alignment software version 7: improvements in performance and usability. Mol. Biol. Evol. 30, 772-780. doi: 10.1093/molbev/mst010

Kim, S. Y., Choi, J. K., Dolan, J. R., Shin, H. C., Lee, S., and Yang, E. J. (2013). Morphological and ribosomal DNA-based characterization of six Antarctic ciliate morphospecies from the Amundsen Sea with phylogenetic analyses. J. Eukaryot. Microbiol. 60, 497-513. doi: 10.1111/jeu.1 2057

Kofoid, C. A., and Campbell, A. S. (1929). A conspectus of the marine and freshwater Ciliata belonging to the suborder Tintinnoinea, with descriptions of new species principally from the Agassiz Expedition to the eastern tropical Pacific, 1904-1905. Univ. Calif. Publ. Zool. 34, 1-403.

Kofoid, C. A., and Campbell, A. S. (1939). The Ciliata: the Tintinnoinea. reports on the scientific results of the expedition to the eastern tropical Pacific, 1904-1905. Bull. Museum Comparative Zool. Harvard 84, 1-473.

Kumar, S., Stecher, G., and Tamura, K. (2016). MEGA7: molecular evolutionary genetics analysis version 7.0 for bigger datasets. Mol. Biol. Evol. 33, 1870-1874. doi: 10.1093/molbev/msw054

Laval-Peuto, M. (1977). Reconstruction d'une lorica de forme Coxliella par le trophonte nu de Favella ehrenbergii (Ciliata, Tintinnina). Comptes Rendus Hebdomadaires Seances l'Academie Sci. Paris Série D 284, 547-550.

Laval-Peuto, M. (1981). Construction of the lorica in ciliata Tintinnina. in vivo study of Favella ehrenbergii: variability of the phenotypes during the cycle, biology, statistics, biometry. Protistologica 17, 249-272.

Laval-Peuto, M. (1994). Classe des Oligotrichea Bütschli, 1887. Ordre des Tintinnida Kofoid et Campbell, 1929. Traité de Zoologie. Anatomie, systématique, biologie. II. Infusoires Ciliés 2, 181-219.

Li, H., Wang, C., Liang, C., Zhao, Y., Zhang, W., Grégori, G., et al. (2019). Diversity and distribution of tintinnid ciliates along salinity gradient in the Pearl River Estuary in southern China. Estuar. Coast. Shelf S. 226:106268. doi: 10.1016/j. ecss.2019.106268

Liao, Y. Y., Liu, Z. Y., He, R. Y., Jiao, N. Z., and Xu, D. P. (2018). Tindinnid ciliates (protozoa, ciliophora) from coastal waters off Xiamen. Acta Hydrobiol. Sin. 42, 1027-1036.

Liu, W. W., Shin, M. K., Yi, Z. Z., and Tan, Y. H. (2020). Progress in studies on the diversity and distribution of planktonic ciliates (Protista, Ciliophora) in the South China Sea. Mar. Life Sci. Technol. 3, 28-43. doi: 10.1007/s42995-02000070-y

Medlin, L., Elwood, H. J., Stickel, S., and Sogin, M. L. (1988). The characterization of enzymatically amplified eukaryotic 16S-like rRNA-coding regions. Gene 71, 491-499. doi: 10.1016/0378-1119(88)90066-2

Minh, B. Q., Nguyen, M. A. T., and von Haeseler, A. (2013). Ultrafast approximation for phylogenetic bootstrap. Mol. Biol. Evol. 30, 1188-1195. doi: $10.1093 / \mathrm{molbev} / \mathrm{mst} 024$

Moreira, D., von, der Heyden, S., Bass, D., López-García, P., Chao, E., et al. (2007). Global eukaryote phylogeny: combined small-and large-subunit ribosomal DNA trees support monophyly of Rhizaria, Retaria and Excavata. Mol. Phylogenet. Evol. 44, 255-266. doi: 10.1016/j.ympev.2006.11.001

Mukherjee, M., Banik, S. K., Pradhan, S. K., Sharma, A. P., Suresh, V., Manna, R. K., et al. (2015). Diversity and distribution of tintinnids in Chilika Lagoon with description of new records. Indian J. Fish. 62, 25-32.

Müller, O. F. (1776). Zoologiae Danicae Prodromus, seu Animalium Daniae et Norvegiae Indigenarum Characteres, Nomina, et Synonyma Imprimis Popularium. Hallageriis: Havniae.

Nakamachi, M., and Iwasaki, N. (1998). List of tintinnids (Protozoa: Ciliata) in Uranouchi Inlet, Kochi, Japan. Bull. Mar. Sci. Fish. Kochi Univ. 18, 65-76.

Nguyen, L.-T., Schmidt, H. A., Von Haeseler, A., and Minh, B. Q. (2015). IQ-TREE: a fast and effective stochastic algorithm for estimating maximum-likelihood phylogenies. Mol. Biol. Evol. 32, 268-274. doi: 10.1093/molbev/msu300

Osorio-Tafall, B. F. (1941). Tintinnidos nuevos o poco conocidos del plancton neritico de México. Revta Soc. Mex. Hist. Nat. 2, 147-173.

Pan, X. M., Bourland, W. A., and Song, W. B. (2013). Protargol synthesis: an in-house protocol. J. Eukaryot. Microbiol. 60, 609-614. doi: 10.1111/jeu.12067 
Park, M.-H., Jung, J.-H., Jo, E., Park, K.-M., Baek, Y.-S., Kim, S.-J., et al. (2018). Utility of mitochondrial CO1 sequences for species discrimination of Spirotrichea ciliates (Protozoa, Ciliophora). Mitochondrial DNA A 30, 148-155. doi: 10.1080/24701394.2018.1464563

Petz, W., and Foissner, W. (1993). Morphogenesis in some freshwater Tintinnids (Ciliophora, Oligotrichida). Eur. J. Protistol. 29, 106-120. doi: 10.1016/S09324739(11)80303-80302

Petz, W., Song, W., and Wilbert, N. (1995). Taxonomy and Ecology of the Ciliate Fauna (Protozoa, Ciliophora) in the Endopagial and Pelagial of the Weddell Sea, Antarctica. Land Oberösterreich: OÖ Landesmuseum.

Ronquist, F., Teslenko, M., Van Der Mark, P., Ayres, D. L., Darling, A., Höhna, S., et al. (2012). MrBayes 3.2: efficient Bayesian phylogenetic inference and model choice across a large model space. Syst. Biol. 61, 539-542. doi: 10.1093/sysbio/ sys029

Roxas, H. A. (1941). Marine protozoa of the Philippines. Philipp. J. Sci. 74, 91-139.

Saber, G. A., Madkour, F. F., Hassan, M. I., and Abu El-Regal, M. A. (2021). An updated checklist of tintinnids (Order: Choreotrichida) in the north western coast of the Red Sea at Hurghada. Alfarama J. Basic Appl. Sci. 2, 297-306. doi: 10.21608/ajbas.2021.77616.1054

Saccà, A., Strüder-Kypke, M. C., and Lynn, D. H. (2012). Redescription of Rhizodomus tagatzi (Ciliophora: Spirotrichea: Tintinnida), based on morphology and small subunit ribosomal RNA gene sequence. J. Eukaryot. Microbiol. 59, 218-231. doi: 10.1111/j.1550-7408.2012.00615.x

Santiago, J. A. M., Furio, E. F., Borja, V. M., Gatdula, N. C., and Santos, M. D. (2017). "First records of tintinnid (Protozoa: Ciliophora: Tintinnina) Species in Manila Bay," in DLSU Research Congress 2017, ed. C. C. Salibay (Manila: De La Salle University).

Santoferrara, L. F., Alder, V. V., and McManus, G. B. (2017). Phylogeny, classification and diversity of Choreotrichia and Oligotrichia (Ciliophora, Spirotrichea). Mol. Phylogenet. Evol. 112, 12-22. doi: 10.1016/j.ympev.2017.03. 010

Santoferrara, L. F., and McManus, G. B. (2021). "Diversity and biogeography as revealed by morphologies and DNA sequences: Tintinnid ciliates as an example," in Zooplankton Ecology, 1st Edn, eds M. A. Teodósio and A. B. Barbosa (Boca Raton, FL: CRC Press), 85-118. doi: 10.1201/9781351021821-7

Santoferrara, L. F., Bachy, C., Alder, V. A., Gong, J., Kim, Y. O., Sacca, A., et al. (2016). Updating biodiversity studies in loricate protists: the case of the tintinnids (Alveolata, Ciliophora, Spirotrichea). J. Eukaryot. Microbiol. 63, 651-656. doi: 10.1111/jeu.12303

Santoferrara, L. F., McManus, G. B., and Alder, V. A. (2013). Utility of genetic markers and morphology for species discrimination within the order Tintinnida (Ciliophora, Spirotrichea). Protist 164, 24-36. doi: 10.1016/j.protis. 2011.12.002

Santoferrara, L. F., Tian, M., Alder, V. A., and McManus, G. B. (2015). Discrimination of closely related species in tintinnid ciliates: new insights on crypticity and polymorphism in the genus Helicostomella. Protist 166, 78-92. doi: 10.1016/j.protis.2014.11.005

Sassi, R., Lima, M. F. D., Galvão, T. C. D. O., and Costa, C. F. (2004). Tintinnina (Potozoa: Ciliophora: Oligotrichida) de águas costeras do nordeste do Brasil. Arquivos Ciências Mar. 37, 15-27.

Schmidt, J. (1902). Some tintinnodea from the Gulf of Siam. Vidensk. Meddel. Naturh. Kjøbenhavn 1901, 183-190.

Skryabin, V. A., and Al-Yamani, F. Y. (2007). New species of genera Leprotintinnus and Luminella (Ciliophora, Spirotrichea, Tintinnida) from Kuwait's waters of the Arabian Gulf. Kuwait J. Sci. Eng. 34:79.

Smith, S. A., Song, W., Gavrilova, N. A., Kurilov, A. V., Liu, W., McManus, G. B., et al. (2018). Dartintinnus alderae n. g., n. sp., a brackish water tintinnid (Ciliophora, Spirotrichea) with dual-ended lorica collapsibility. J. Eukaryot. Microbiol. 65, 400-411. doi: 10.1111/jeu.12485

Sniezek, J. H., Capriulo, G. M., Small, E. B., and Russo, A. (1991). Nolaclusilis hudsonicus n. sp. (Nolaclusiliidae n. fam.) a bilaterally symmetrical tintinnine ciliate from the lower Hudson River estuary. J. Protozool. 38, 589-594.

Snyder, R. A., and Brownlee, D. C. (1991). Nolaclusilis bicornis n. g., n. sp. (Tintinnina Tintinnidiidae): a tintinnine ciliate with novel lorica and cell morphology from the Chesapeake Bay estuary. J. Protozool. 38, 583-589.

Sonnenberg, R., Nolte, A. W., and Tautz, D. (2007). An evaluation of LSU rDNA D1-D2 sequences for their use in species identification. Front. Zool. 4:6. doi: 10.1186/1742-9994-4-6

Strelkow, A. A., and Wirketis, M. A. (1950). New planktonic infusorian (suborder Tintinnoinea) from Peter the Great Bay. Rep. USSR Acad. Sci. 74, 389-391.

Talavera, G., and Castresana, J. (2007). Improvement of phylogenies after removing divergent and ambiguously aligned blocks from protein sequence alignments. Syst. Biol. 56, 564-577. doi: 10.1080/10635150701472164

Wang, C. C., and Nie, D. (1932). A survey of the marine protozoa of Amoy. Contr. Biol. Sci. Soc. China 8, 283-385.

Wang, Y., Zhang, W., Lin, Y., Cao, W., Zheng, L., and Yang, J. (2014). Phosphorus, nitrogen and chlorophyll-a are significant factors controlling ciliate communities in summer in the northern Beibu Gulf, South China Sea. PLoS One 9:e101121. doi: 10.1371/journal.pone.0101121

Wasik, A., and Mikolajczyk, E. (1994). Infraciliature of Cymatocylis affinis/convallaria (Tintinnina). Acta Protozool. 33, 79-85.

Xu, D. P., and Song, W. B. (2005). Tintinnid ciliates from Qingdao (Protozoa, Ciliophora, Tintinnida). Acta Zool. Sin. 30, 501-508.

$\mathrm{Xu}$, D. P., Sun, P., Shin, M. K., and Kim, Y. O. (2012). Species boundaries in tintinnid ciliates: a case study-morphometric variability, molecular characterization, and temporal distribution of Helicostomella species (Ciliophora, Tintinnina). J. Eukaryot. Microbiol. 59, 351-358. doi: 10.1111/j.1550-7408.2012.00625.x

Yoo, K., Kim, Y.-O., and Kim, D.-Y. (1988). Taxonomical studies on tintinnids (Protozoa: Ciliata) in Korean coastal waters. 1. Chinhae Bay. Bull. Korean Fish. Soc. 4, 67-90.

Yousif Al-Yamani, F., Skryabin, V., Gubanova, A., Khvorov, S., and Prusova, I. (2011). Marine Zooplankton Practical Guide for the Northwestern Arabian Gulf. Kuwait: Kuwait Institute for Scientific Research.

Zhang, Q. Q., Agatha, S., Zhang, W. C., Dong, J., Yu, Y., Jiao, N. Z., et al. (2017). Three rDNA loci-Based phylogenies of tintinnid ciliates (Ciliophora, Spirotrichea, Choreotrichida). J. Eukaryot. Microbiol. 64, 226-241. doi: 10.1111/ jeu.12354

Zhang, W., Jiang, Y., Li, J. Q., Ma, H. G., and Xu, H. L. (2012). Tintinnid ciliates from costal waters off Guangdong, with notes on three new records of China (Protozoa, Ciliophora). Acta Hydrobiol. Sin. 36, 744-750.

Zingel, P., Agasild, H., Karus, K., Buholce, L., and Noges, T. (2019). Importance of ciliates as food for fish larvae in a shallow sea bay and a large shallow lake. Eur. J. Protistol. 67, 59-70. doi: 10.1016/j.ejop.2018.10.004

Conflict of Interest: The authors declare that the research was conducted in the absence of any commercial or financial relationships that could be construed as a potential conflict of interest.

Publisher's Note: All claims expressed in this article are solely those of the authors and do not necessarily represent those of their affiliated organizations, or those of the publisher, the editors and the reviewers. Any product that may be evaluated in this article, or claim that may be made by its manufacturer, is not guaranteed or endorsed by the publisher.

Copyright (c) $2022 \mathrm{Hu}$, Wang, Liu and Lin. This is an open-access article distributed under the terms of the Creative Commons Attribution License (CC BY). The use, distribution or reproduction in other forums is permitted, provided the original author(s) and the copyright owner(s) are credited and that the original publication in this journal is cited, in accordance with accepted academic practice. No use, distribution or reproduction is permitted which does not comply with these terms. 